\title{
Bridging the Form and Function Gap in Urban Green Space Design through Environmental Systems Modeling
}

\author{
K. N. Irvine, ${ }^{1}$ Ho Huu Loc, ${ }^{2}$ Chansopheaktra Sovann, ${ }^{3}$ Asan Suwanarit, ${ }^{1}$ Fa Likitswat, ${ }^{1}$ Ranjna Jindal, ${ }^{4}$ \\ Thammarat Koottatep, ${ }^{2}$ J. Gaut, ${ }^{5}$ L. H. C. Chua, ${ }^{5}$ Lai Wen Qi, ${ }^{6}$ and Koen De Wandeler ${ }^{7}$ \\ ${ }^{1}$ Thammasat University, Thailand; ${ }^{2}$ Asian Institute of Technology, Thailand; ${ }^{3}$ Royal University of Phnom Penh, Cambodia; ${ }^{4}$ Mahidol University, \\ Thailand; ${ }^{5}$ Deakin University, Geelong, VIC, Australia; ${ }^{6}$ Nanyang Technological University, Singapore; ${ }^{7}$ KU-Leuven, Campus Sint-Lucas
} Ghent, Belgium.

\begin{abstract}
Using a case study approach from past projects in Singapore, Australia, Cambodia, Thailand and Vietnam, we examine the benefits, but also some of the challenges, to implementing green space in urban design. Green space can have multiple physical and psychological wellbeing benefits, as well as environmental benefits, including urban runoff quantity and quality management, urban heat island abatement, air quality improvement, and noise reduction. Water sensitive urban design (WSUD) can be an important element of green space design and here we explore how modeling of ecosystem services and dynamic modeling of WSUD can help to facilitate sound planning and management decision making in support of green space implementation. As we illustrate with examples for Australia, Singapore and Cambodia, we believe that application of an urban ecosystem services modeling approach can elucidate environmental benefits of urban green space that otherwise may not be considered. Engineers may include dynamic modeling of WSUD in support of an urban master plan, or urban redevelopment, but generally urban planners are less conversant in applying models. We discuss some of the challenges to integrating multidisciplinary visioning and modeling of green space design and performance evaluation through our experience with a stormwater and wastewater design study for Cha Am, Thailand, that included landscape architecture and engineering classes at Thammasat University, Mahidol University, and AIT. Through a case study of Phnom Penh, we illustrate how modeling and 3D visualization can be used to effectively explore the benefits of green space. We conclude that a user-friendly decision support system is needed to integrate modeling and visualization tools and thereby bridge the gap between form and function in urban green space design.
\end{abstract}

\section{Introduction}

Models are a means to represent complex systems in ways that provide us with insights on how these systems operate and how they might be further developed and managed. We might consider three general types of models: hardware (or physical) models, analogue models, and mathematical (or numerical) models. In architectural design and some branches of engineering, hardware models are used extensively, but in this paper our objective is to examine different approaches in the application of mathematical models to better understand the dynamics of the urban environment in support of green space planning. In particular, we will explore the opportunities of applying an ecosystem services approach to model the value of green space in urban areas as well as the application of dynamic hydrologic-hydraulic models to assess performance of green space planning scenarios. Collectively, these models can be used to characterize, plan, and manage urban environmental systems, but at the moment these model- ing approaches are done separately, and often independently. We conclude there is a need to seamlessly link these modeling approaches into a user-friendly decision support system.

Low impact development (LID), also known variously as water sensitive urban design (WSUD), sustainable urban drainage systems (SUDS) or sponge cities, is traditionally considered to be a decentralized, microscale design approach to stormwater management that includes some combination of features such as raingardens, grassed swales, green roofs, permeable pavement, constructed wetlands, rainwater harvesting, and tree preservation. The intent is to mimic natural hydrologic processes by re-connecting the urban surface to the underlying soil, which facilitates infiltration and storage. In fact, WSUD potentially represents a dual benefit of reducing localized flooding and improving runoff quality (through filtration and adsorption). WSUD has received attention globally (Selbig and Balster 2010; Garrison and Hobbs 2011; Carson et al. 2013; Irvine et al. 2014; Fletcher et al. 2015; Lim and Lu 2016; Kok et al. 2016; Yau et al. 2017; Murphy et

Irvine, K.N., Ho Huu Loc, Chansopheaktra Sovann, Asan Suwanarit, Fa Likitswat, Ranjna Jindal, Thammarat Koottatep, J. Gaut, L.H.C. Chua, Lai Wen Qi, and Koen De Wandeler. 2021. "Bridging the Form and Function Gap in Urban Green Space Design through Environmental Systems Modeling." Journal of Water Management Modeling 29: C476 https://doi.org/10.14796/JWMM.C476.

(c) CHI 2021. www.chijournal.org ISSN 2292-6062. 
al. 2018; Zevenbergen et al. 2018; Jiang et al. 2018; Lashford et al. 2019; Nguyen et al. 2019) but adoption has been variable, even within a country (Marsalek and Schreier 2009; Morison and Brown 2011; Torgersen et al. 2014; Nguyen et al., 2019). In this paper, we expand the traditional definition of WSUD to include larger green space areas such as parks, urban forests and natural wetlands. We will see that the modeling approaches described herein can be applied to different spatial scales, given appropriate consideration of the green space form and function.

We will use case studies from our past work in Singapore, Australia, Cambodia, Thailand and Vietnam to discuss how models can be applied in addressing issues of green space and urban planning.

\section{Urban Green Space in an Historical Con- text}

Society has long valued green space and preservation of nature, with one of the world's earliest wildlife sanctuaries being established during the third century BCE in Sri Lanka, by King Devanampiyatissa (Hochegger 1998). Yellowstone National Park was the first national park in the United States (1872) and this was followed soon after by the founding of the Royal National Park near Sydney, Australia (1879). The forest preserve of Bukit Timah, Singapore, was established in 1883 (Corlett 1988) and contains the largest surviving area of primary rain forest in the country (Corlett 1990; Yee et al. 2011).

Within urban areas, the early western planning traditions, such as the medieval bastide, Spanish Laws of the Indies towns, and the English renaissance included central plazas or commons spaces, and parks (Blumenfeld 1949; Lowenthal and Prince 1965), although as Stanley et al. (2012) note "In ancient states, large gardens and parks were usually royal or elite installations and had only sporadic or selective public access." In North America, the focus on urban green space planning can be linked to the remarkable vision and designs of Frederick Law Olmsted (ca. 1857-1895), including Central Park in New York City (Howett 1998; Rybczynski 1999). Olmsted often used both pastoral and picturesque styles in his plans where the pastoral featured vast expanses of green with small lakes, trees and groves, and produced a soothing, restorative effect, while the picturesque included rocky, broken terrain with shrubs and creepers that emphasized nature's richness. His design of Llewellyn Park in 1857, an English-inspired suburb of New Jersey, included expanses of forest, parkland, and water features. A relative contemporary of Olmsted's, Ebenezer Howard, promoted the garden city concept in which town and country were integrated, with the plan including extensive green space that would enhance community and environmental wellbeing (Howard 1902; Clark 2003). Howard also outlined the early concepts of what we now call a circular economy (Riggs 2017).

More recently, in his seminal 1969 book Design with Nature, landscape architect lan McHarg argued that science and ecology must underpin and direct regional and urban development so that even in existing cities we "see the components of the natural identity of the city as a value system, offering opportunities for human use... It is, therefore, essential to understand the city as a form, derived in the first instance from geological and biological evolution, existing as a sum of natural processes and adapted by man." In some ways, the ideas of McHarg were a blueprint for ecological or eco-city planning that has evolved to embrace planning concepts such as WSUD, where the primary guiding principle is the belief that cities should function in the same way as natural ecosystems and reflect natural patterns of sustainability (Wittig 2008; Wong and Yuen 2011). An important element of eco-city planning is the use of appropriate green technologies for water, energy and waste management (Kenworthy 2006; Wong and Yuen 2011).

Miao (2013) notes that "One cannot overstate the importance of public places," but also warns "Asia Pacific urban public places share several features which distinguish them from those in the Western cities," so while comparisons between Asian and Western cities may be valuable, care must be taken in making these comparisons. Certainly, cities in Asia have their own histories of green space planning and preservation. For example, while Japan's modern age of urban forest management was ushered in around 1870, the Arashiyama National Forest, located in the northwestern part of Kyoto, existed as a public landscape from 1255 (Fukamachi et al. 2000). Smaller village shrines (chinjunomori) and local shrines (uji-gami) have been components of Japan's landscape since around the tenth century. The forests, shrines and Buddhist temples represent a complex interaction of Shintoism and Buddhism, with forests (and Buddhist temples) protecting shrines and kami, spirits or elements of the landscape (Iwatsuki 2009), suggesting that such green space provided both spiritual and physical benefits. Yet while there may be differences in Asian and Western planning traditions, the marks of Western colonialism are indelibly etched in many Southeast Asian urban landscapes. Although there is some evidence that the living areas in Angkor Wat, the centrepiece of the twelfth century Angkor kingdom, contained formal gardens (Evans and Fletcher 2015), by 1890 open public spaces and public buildings of French colonial character began to appear in Phnom Penh, the modern capital of Cambodia (Molyvann 2003). In the Phnom Penh of today we see a mix of modern, French colonial, traditional Khmer, and fusion design styles.

\section{Societal and Environmental Benefits of Urban Green Space}

Jones (2018) has noted:

Green spaces that were open to a (selective) public consistently invoked a vernacular of health within a complicated cultural ecology layered with patronage and embedded social capital. Henry IV established the Place Royale (now Vosges) in 1605 out of concern that the people of Paris needed 'a place to promenade' as they were 'closely pressed together in their houses.' The city of London, too, featured a plethora of royal parks 
including Greenwich (1433), St James' (1532), Hyde (1536) and Richmond (1637) that made the transition from royal hunting reserves into spaces for social and environmental respite in various shapes and sizes, each motivated largely by concerns about ever-encroaching urban space in the western hinterlands of the city.

The historical view of green space as the "lungs of the city," which provided a restorative tonic for the health of urbanites, has been well documented by Jones (2018) and in general the environmental and societal benefits of urban green space have long been recognized (Sanders 1986; Marsh 1991; McPherson 1992; Swanwick et al. 2003; Chiesura 2004; De Ridder et al. 2004; Sherer 2006; Fuller et al. 2007; Millward and Sabir 2011; Strohbach et al. 2012; Wolch et al. 2014; Ng 2015; Loc et al. 2018a; 2018b).

Increasingly, psychological and physical wellbeing have been linked to concepts of community wellbeing, happy cities (and sustainable happiness), resiliency, liveability, and sustainability (e.g. Tzoulas et al. 2007; Cutter et al. 2008; O'Brien 2008; Grahn and Stigsdotter 2010; Michalos et al. 2011; Ballas 2013; Brooks 2013; Brown et al. 2013; Wilson and Tyedmers 2013). However, except in cases of extreme toxicity (e.g. children's health impacts due to lead poisoning; Levin et al. 2008), subtler physical health impacts related to the urban environment can be difficult to detect quantitatively without a substantial epidemiological study (Maas et al. 2006). Lee and Maheswaran (2011) conducted a literature review of 485 articles, with 35 being reviewed in extensive detail and concluded:

There is weak evidence for the links between physical, mental health and wellbeing, and urban green space. Environmental factors such as the quality and accessibility of green space affect its use for physical activity. User determinants, such as age, gender, ethnicity and the perception of safety, are also important. However, many studies were limited by poor study design, failure to exclude confounding bias or reverse causality and weak statistical associations.... That said, the reported findings in studies were generally consistent and supported the current view that urban design can facilitate physical activity and reduce impediments to exercise.

The complexity of exploring the interrelations between urban form and function that impact human health and wellbeing are illustrated in Figure 1. Land use and public resources (such as parks) are denoted in Figure 1 as intermediate social determinants of health. These intermediate determinants are connected to proximate social determinants such as environmental stressors and health behaviours, which are then linked to multiple health and wellbeing outcomes. Many of the intermediate and proximate determinants are directly impacted by urban form and function and may be positively managed by sustainable urban planning.

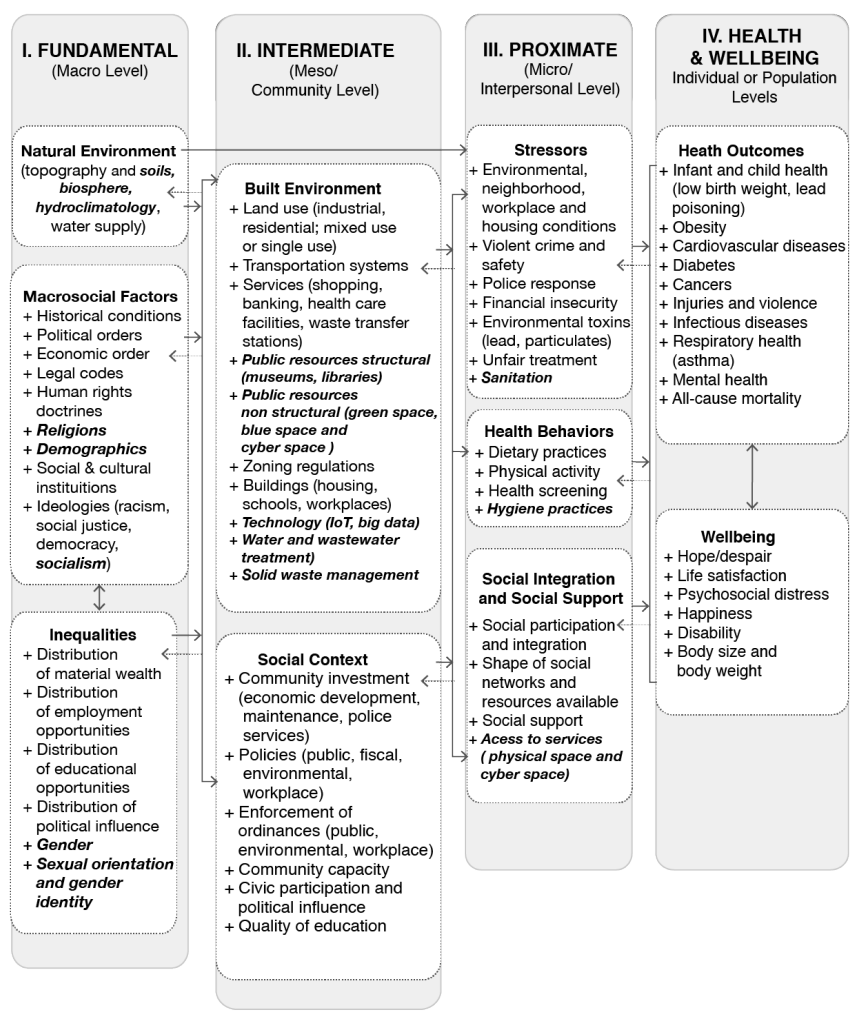

Figure 1 Social determinants of health (modified from Northridge et al. 2003); our modifications (italicized bold) of the original emphasize issues in urban areas of less developed countries and have been updated to consider current planning trends towards ICT solutions and to explicitly show aspects of the hydrosphere and biosphere.

Figures 2 and 3 present air temperatures for two parks in Bangkok, Thailand, and are used to underscore the interactions between urban form, function and wellbeing shown in Figure 1. Temperatures for Lumphini Park (Figure 2) were measured on 2016-12-17 between 14:15 $\mathrm{h}$ and 15:15 h, while temperatures at Chatuchak Park (Figure 3) were measured on 2016-12-18 between 11:00 $\mathrm{h}$ and 12:30 h. The temperatures in Lumphini Park were highest near the paved entrance and adjacent to a busy thoroughfare, Ratchademri Road. The coolest temperatures were adjacent to the park's waterbodies. The eastern section of Chatuchak Park showed a remarkable thermal pattern, with the temperatures near the busy highway exchange being at least $4{ }^{\circ} \mathrm{C}$ warmer than the southwest side of the park, itself adjacent to green space. Elevated temperatures associated with the urban heat island effect (intermediate and proximate determinants, Figure 1) may negatively impact human health (Smargiassi et al. 2009; Tan et al. 2010; Laaidi et al. 2011; Gabriel and Endlicher 2011), but prudent use of green space, as suggested by Figures 2 and 3, could mitigate elevated temperatures (Wong et al. 2005; Yu and Hien 2006; Rizwan et al. 2008; Gunawardena et al. 2017). 


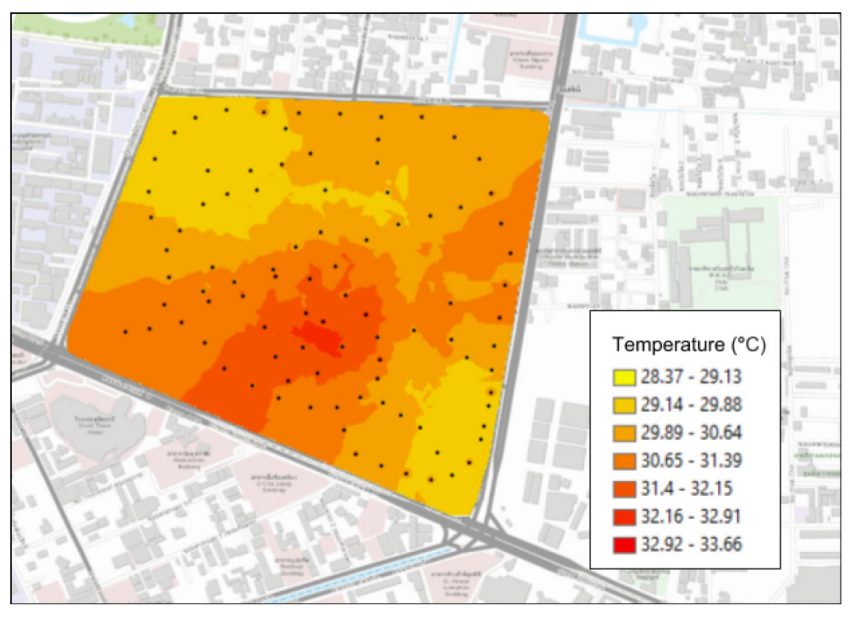

Figure 2 Air temperatures measured at Lumphini Park, Bangkok; measurements were made by student teams using handheld Kestrel 4000 weather trackers held at arm's length above their heads.

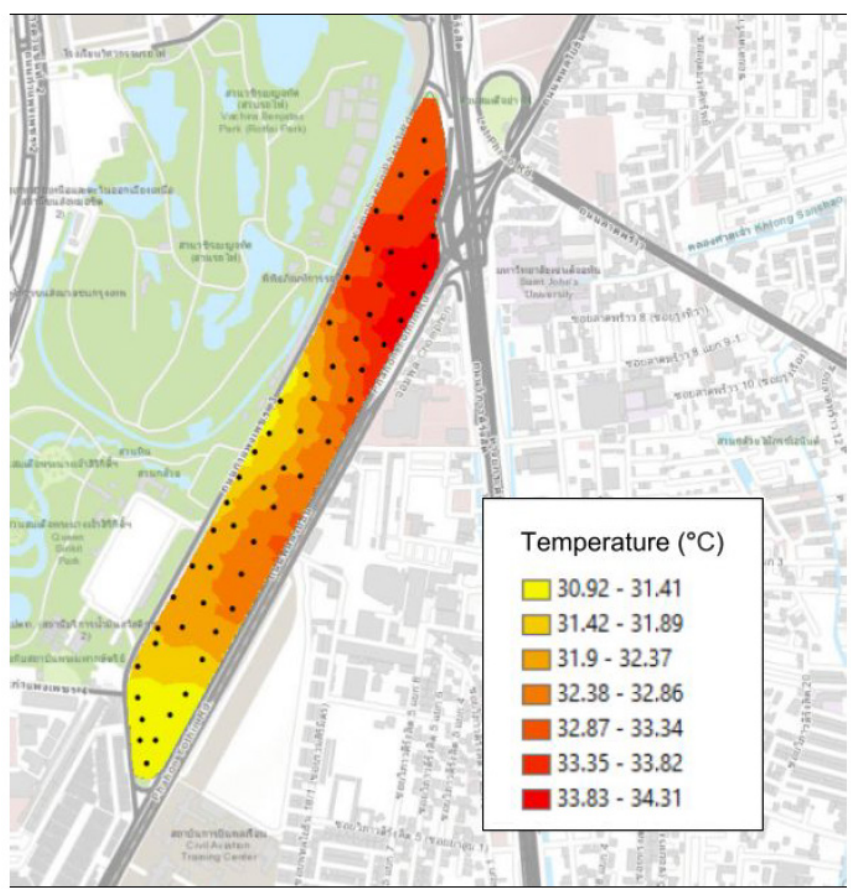

Figure 3 Air temperatures measured in the eastern section of Chatuchak Park, Bangkok; measurements were made by student teams using handheld Kestrel 4000 weather trackers held at arm's length above their heads.

\section{Water Sensitive Urban Design as an Ele- ment of Urban Green Space}

The concept of WSUD appears to have been formally initiated in the state of Maryland in the early 1990s as an alternative approach to centralized best management practices and drainage systems with end-of-pipe treatment. In some ways, WSUD might be considered a natural progression of earlier concepts outlined by McHarg and Mumford (1969) and eco-city planning explored during the mid-1970s by the Urban Ecology group in Berkeley, California (Roseland, 1997). Some issues have been raised about WSUD efficacy in managing larger storm events, but since 2006 Singapore has aggressively implemented a variety of WSUD technologies in a coordinated plan that has successfully managed the runoff in a tropical climate (e.g. Irvine et al. 2014; Loc et al. 2020) (Figure 4).
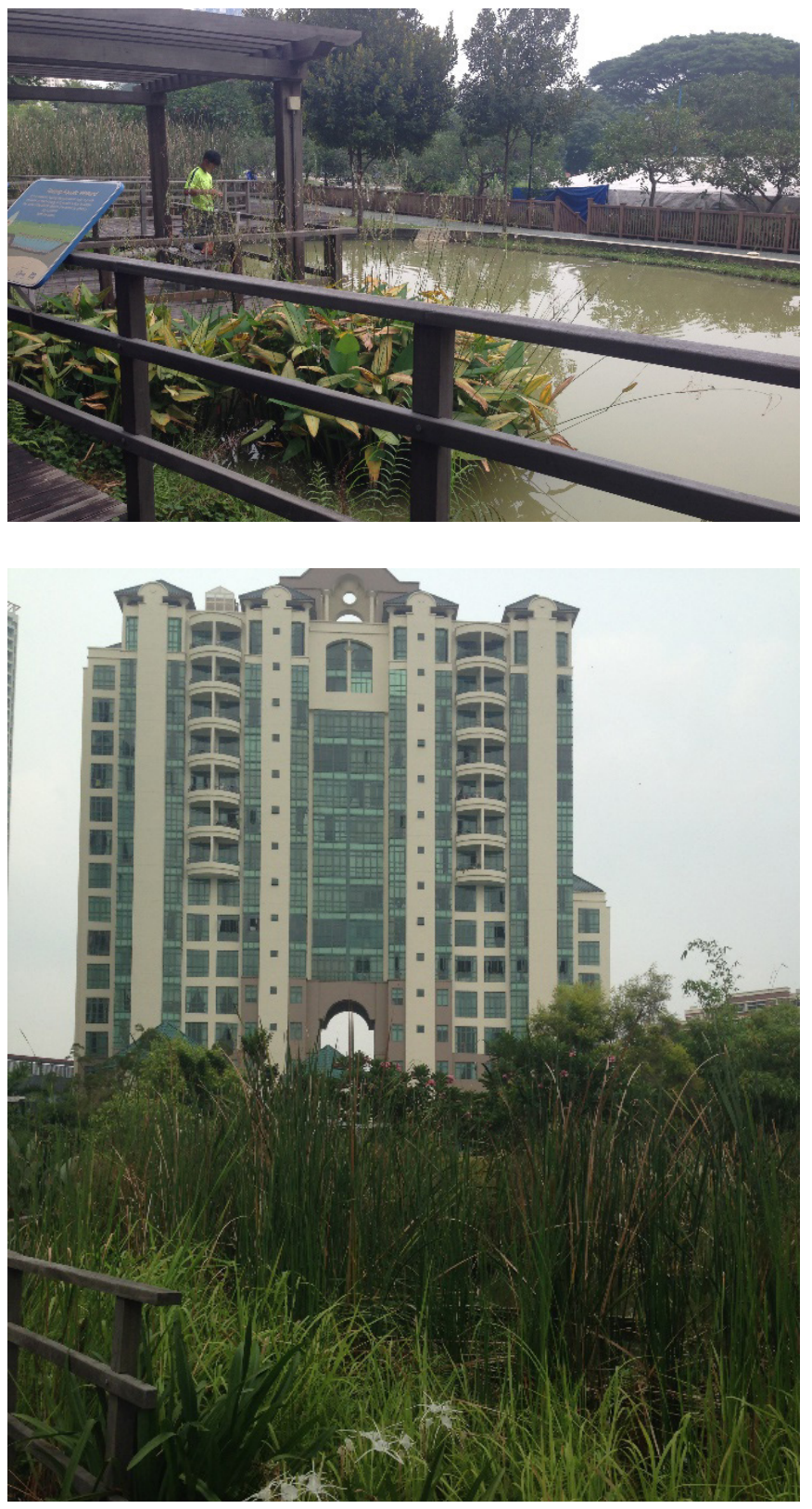

Figure 4 (upper) Alexandra Canal ABC Waters Learning Trail, with a constructed wetland and (lower) sedimentation bay (photos by author). 
In 1967 then Prime Minister Lee Kuan Yew introduced Singapore's garden city vision, with the initial phase being an intensive tree planting program along major roads and streets, as well as the camouflaging of concrete structures by creepers and climbers. Yuen (1996) maintained that Singapore's garden city plan had little in common with Howard's earlier garden city vision, although this perhaps could be debated. By 1998 Singapore's garden city concept expanded into the current greening policy of City in a Garden (http:// eresources.nlb.gov.sg/history/events/a7fac49f-9c96-40308709-ce160c58d15c; Yuen 1996). Recent work conducted by MIT using a green view index (e.g. Li et al. 2015) that assesses canopy cover at street level through Google Street View determined Singapore to be one of the top green cities of the world, despite a population density of 7797 people $/ \mathrm{km}^{2}$ (http://senseable.mit.edu/treepedia).

The ABC (Active, Beautiful, Clean) Waters Programme was initiated by the Public Utilities Board (PUB), Singapore's water agency, to reconnect Singaporeans with the water, increase urban liveability, and effectively manage urban runoff quantity and quality. $A B C$ Waters features include vegetated swales, bioretention swales, sedimentation bays, raingardens, constructed wetlands, cleansing biotopes, and naturalization of formerly concrete drainage canals (e.g. Figure 4). The concept has been adopted by more than 300 partners, and by 2018 there were 75 ABC Waters Certified projects. Also, beginning in 2018, the Singapore Housing and Development Board (HDB) began incorporating $A B C$ features to treat storm water runoff from at least $25 \%$ of the site area in all new public housing developments (MEWR 2018). With more than $80 \%$ of Singapore residents living in public housing, this commitment constitutes a significant effort to mainstream $A B C$ Waters. The ABC Waters Programme includes learning trails that are physically and virtually signed, providing educational material for schools and lifelong learning (e.g. Figure 4). In fact, Singapore's community engagement starts with the young generation as water issues are fully integrated into the lower secondary through junior college and university curriculums (Irvine et al. 2015a), including school adoption of local $A B C$ projects. PUB has constructed raingardens at 13 schools, serving as teaching aids to demonstrate how natural materials, such as plants and soil media, can be used to cleanse stormwater runoff (MEWR 2018). The raingarden program also has been extended to universities (Chang et al. 2018). Most recently PUB combined the unveiling of the Kallang River@Bishan-Braddell Road ABC Waters project with the local Mid-Autumn celebration and a model raingarden design competition for secondary schools in a full day of activities that brought community and schools to the water (Figure 5).

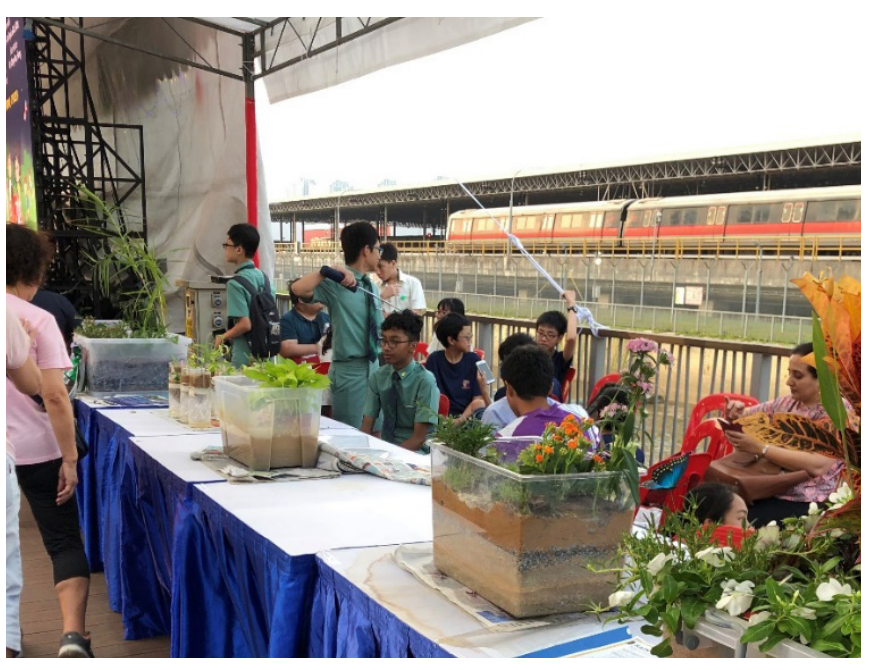

Figure 5 Secondary school raingarden design competition sponsored by PUB, September 2019 (photo by author).

\section{How Can Ecosystem Services Assess- ment Be a Modeling Tool to Help Promote Green Urban Design?}

Turner et al. (2011) defined ecosystem services as aspects of ecosystems consumed or utilized to produce human wellbeing. The Millennium Ecosystem Assessment (MA 2005) suggested there were four categories of ecosystem services: supporting (e.g. nutrient cycling, soil formation, primary production); provisioning (e.g. food, water, fiber); regulating (e.g. climate regulation, disease regulation, water purification); and cultural (e.g. spiritual, religious, aesthetic). Subsequent to Costanza et al.'s (1997) landmark study in which it was concluded that the value of ecosystem services for the entire biosphere was $\$ 16-54$ trillion 1994 USD per year, with an average of \$33 trillion 1994 USD per year (or about double the global GNP in 1994), there has been extensive examination of methodologies to monetize ecosystem services (Loomis et al. 2000; Turner et al. 2011; Gómez-Baggethun and Ruiz-Pérez 2011; Braat and de Groot 2012; Christie et al. 2012; Costanza et al. 2017). Research also has evolved beyond monetization to examine other methods (including indicator approaches, participatory mapping, multi-criteria decision analysis, and mixed method approaches) in assessing ecosystem services (Christie et al. 2012; Martín-López et al. 2012; Crossman et al. 2013; Kelemen et al. 2014; Scholte et al. 2015; Wong et al. 2015; Kremer et al., 2016; Saarikoski et al., 2016; Meri and Lian 2017; Loc et al. 2018a). While challenges still exist to mainstreaming ecosystem service assessments in planning practice (e.g. Sitas et al. 2014; Loc et al. 2018b; 2020), it is instructive to consider the services potentially provided by green space in urban areas (Table 1). The ecosystem services provided by a particular green space will vary from opportunity to opportunity. For example, a small raingarden will primarily provide runoff regulating services, wellbeing services 
through aesthetics, and to a much lesser extent supporting services (e.g. biodiversity). A large park might provide all of the regulating, supporting, and cultural services noted in Table 1, while natural wetland areas (as discussed below) also can provide provisioning services.

Table 1 Possible ecosystem services provided by urban green space

\begin{tabular}{ll}
\hline \multicolumn{1}{c}{ Category } & \multicolumn{1}{c}{ Example } \\
\hline Regulating & Runoff quantity (flood control) \\
& Runoff quality \\
& Temperature (urban heat island) \\
& Air quality \\
& Noise \\
& Climate (carbon sequestration) \\
\hline Supporting & Biodiversity \\
\hline Provisioning & Food (in the case of per urban wetlands, for example, both \\
& terrestrial and aquatic crops; fishing; snail harvest) \\
& Water (in the case of periurban wetlands) \\
& Clothing (e.g. bamboo fibre in the case of forests) \\
& Physical activity \\
& Social interaction \\
& Tourism \\
& Wellbeing \\
& Spiritual
\end{tabular}

Ecosystem service concepts have been used to assess values of green infrastructure (or WSUD) but in a review of 170 papers Prudencio and Null (2018) found that $<40 \%$ actually quantified ecosystem services. Haase et al. (2014) noted that of the 217 papers they reviewed, 156 (72\%) exclusively employed nonmonetary indicators in urban ecosystem service assessments, while 77 (35\%) used both monetary and nonmonetary methods. In monetizing ecosystem services for green infrastructure, contingent valuation (willingness to pay), hedonic pricing, direct market price, avoided costs, and willingness to travel approaches have been used (Tapsuwan et al. 2009; Mekala et al. 2015; Lupp et al. 2016; Park et al. 2017; Fan and Matsumoto 2019). However, there is a need to strengthen the empirical evidence of benefits provided by WSUD design and also explore possible differences in valuation characteristics, including comparisons of these monetization approaches with the emerging application of multi-criteria decision analysis (e.g. Saarikoski et al., 2016).

One of our recent studies used a hedonic pricing approach to compare the value of ecosystem services provided by green space in Geelong, Australia and Singapore (Irvine et al. 2020). Greater Geelong maintains more than 200 small streetscape scale and 150 large end-of-pipe WSUD assets and our study explored the value of an award-winning constructed wetland system in the Grand Lakes Estate development (Figure 6). The entire constructed wetland occupies an area of 14.6 ha, but our study examined only the most recently completed segment, having an area of 6.1 ha. We employed hedonic pricing to monetize the ecosystem services provided by the wetland, with real estate data for all properties sold in Grand Lakes in 2017 being collected through a local newspaper. The hedonic pricing method showed that distance to the wetland, number of bathrooms, number of car lots, and size of lot accounted for $55.1 \%$ of the variability in home sales price. Holding other variables constant, the marginal implicit price for the constructed wetland in Geelong declined by \$117 AUD (\$106 SGD) if the property was $1 \mathrm{~m}$ further away than the mean distance to the wetland. In Singapore, we analysed data associated with the sales price for HDB flats in the vicinity of Bishan Park, which includes a section of the Kallang River that was converted in 2012 from a straight concrete channel to a naturalized meandering system with a functioning floodplain (Figure 6) and cleansing biotope. Moving $1 \mathrm{~m}$ further from mean distance to the naturalized river and park system produced a decrease in marginal implicit price of \$92 SGD (\$101 AUD) for the HDB flats (2017 sales data). The distance to the park, floor level (story) of the flat, number of rooms, and years remaining on the lease, accounted for $86 \%$ of the flat sales price. Key informant interviews and citizen surveys conducted at both locations qualitatively confirmed the results of the hedonic pricing analysis with respect to the general desirability of green space.
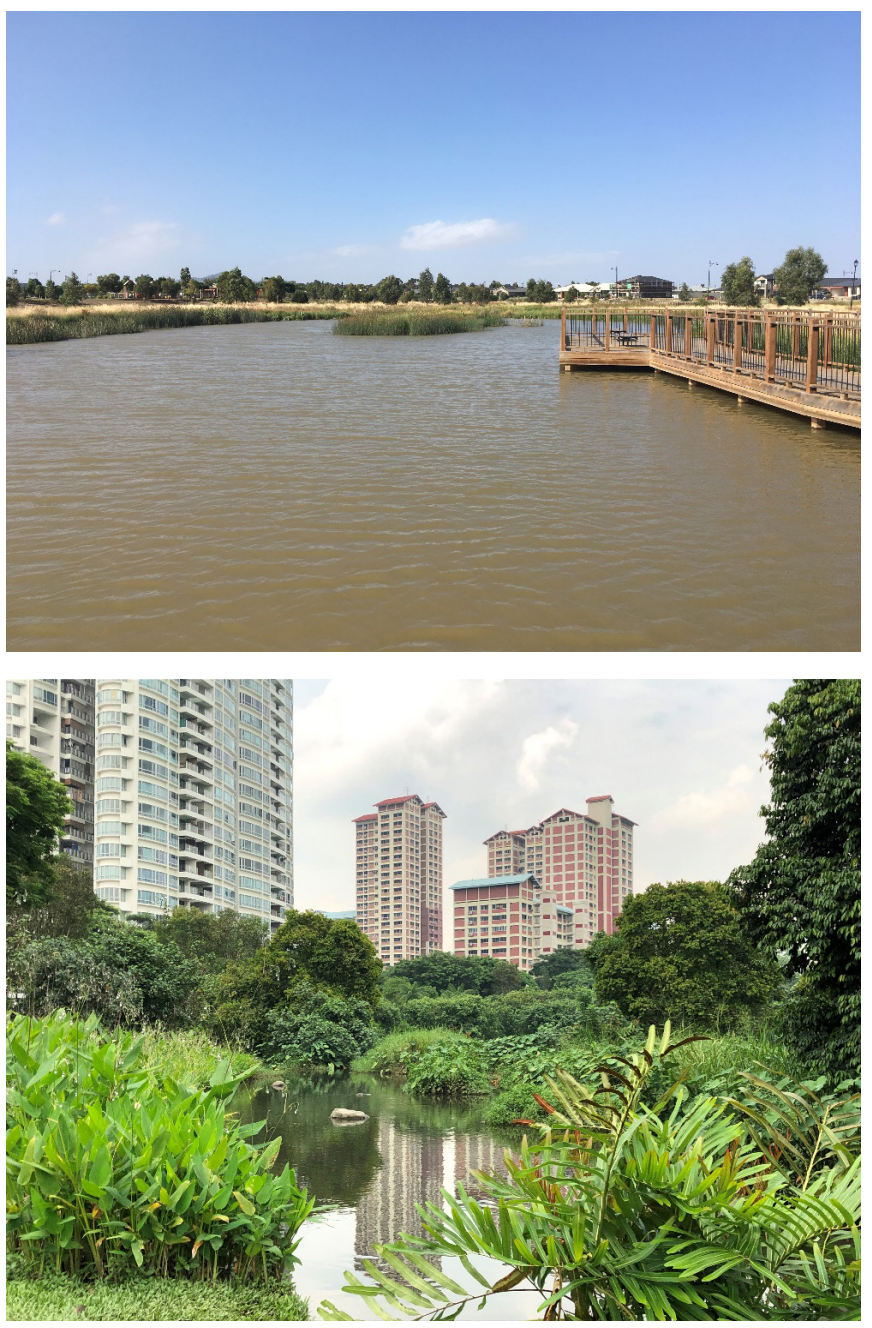

Figure 6 (upper) Grand Lakes Estate constructed wetland, Australia and (lower) Bishan Park and Kallang River (photos by the author). 
At a different spatial scale and with different form and function, the city of Phnom Penh, Cambodia treats its wastewater using a system of naturally occurring wetlands. Beginning in 2006, we undertook a series of studies to assess the treatment efficacy of the 1500 ha Boeng Cheung Ek wetland that receives waste and stormwater from the southern portion of the city. Our studies included both sampling and dynamic modeling to assess current conditions and evaluate treatment efficacy scenarios related to infilling for urban development (e.g. Visoth et al. 2010; Sothea et al. 2010; Irvine et al. 2015b). More recently, however, we have begun to evaluate the ecosystem services provided by the wetland (e.g. Ro et al. 2020). These services include provisioning (Figure 7), as the area is home to an active peri-urban agriculture and fishing community; regulating (wastewater treatment, stormwater runoff storage and flood control, urban heat island, carbon sequestration, air quality), supporting (biodiversity), and cultural (the western edge of the wetland borders a killing field from the Khmer Rouge era). We have not monetized all services provided by the wetland, but to date, services have been evaluated using a direct market approach to estimate the value of food and water provisioning and an indirect avoidance expenditure approach to estimate the value of wastewater treatment. The most likely value for food and water provisioning and wastewater treatment (which does not include consideration of benefits to downstream communities, such as Vietnam's Mekong Delta) is $\$ 30.1$ million USD per year, but with a range of \$15.7-49 million USD per year (Ro et al., 2020).

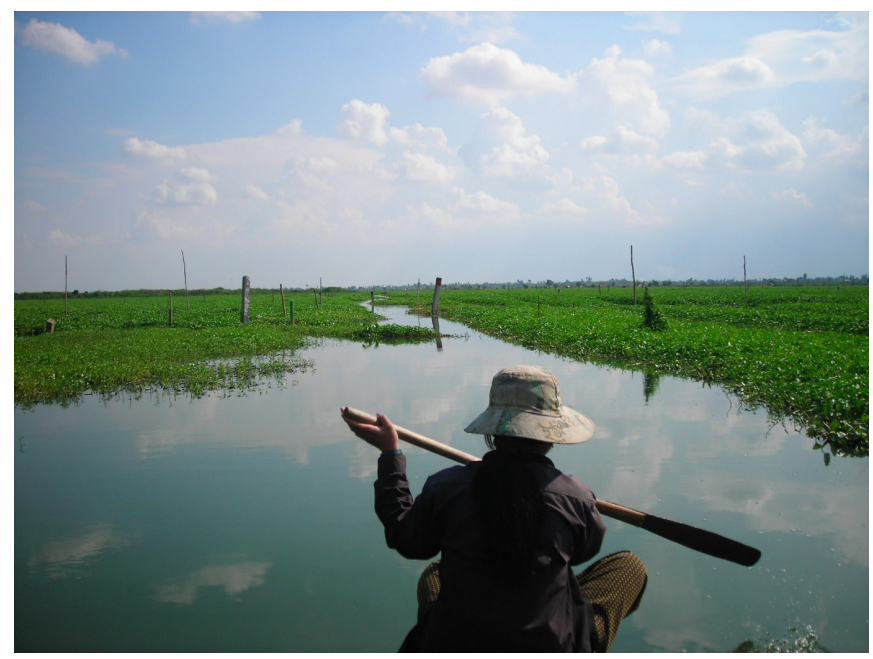

Figure 7 Boeng Cheung Ek wetland with peri-urban agriculture (water spinach) provisioning services (photo by author).

Cultural ecosystem services, for example those associated with the killing field, can be more challenging to monetize. Loc et al. (2018a) took a different approach to evaluate cultural ecosystem services in an area of Kien Giang Province on the west coast of the Mekong Delta in Vietnam. They employed two survey-based (richness and quality of ecosystem services) and one GIS-based (willingness to travel, WTT) indices to evaluate the cultural benefits derived from seven popular tourism sites. The measurements of quality and richness detected both synergies and tradeoffs among the evaluated benefits, supporting the need to balance management between developing tourism activities and preserving the cultural identity of the landscapes. The WTT considers frequency and the potential costs in traveling to a particular site and is an alternative to the willingness to pay (contingent valuation) approach. The WTT analysis identified various preferences in recreational travelling for different communities within the Kien Giang study area.

Ecosystem services evaluations, as illustrated here, provide a diverse and flexible modeling framework that can yield important information for municipalities when assessing benefits and costs of implementing WSUD or preserving green space. However, ecosystem services evaluations do not provide guidance on the design or performance evaluation of the green infrastructure. For that, we must rely on dynamic hydrologic-hydraulic modeling. But how can planners and architects effectively implement these modeling tools? To explore this question we will begin by contrasting the planning or architectural visioning process of the urban landscape with that of the engineer.

\section{Visioning Urban Landscape and Green Space-the Planning and Landscape Architecture Approach}

Growing environmental awareness and activism during the $1960 \mathrm{~s}$ (Carson 1962; Hardin 1968; Commoner et al. 1971; Ehrlich 1971; Meadows et al. 1972) led to the establishment of the Environmental Protection Agency (USEPA) in the United States as well as the passing of the National Environmental Policy Act (NEPA) of 1970. NEPA provided the foundation that required environmental values, including aesthetics, to be included in development decision making and a similar path was being taken concurrently in the United Kingdom and Europe (Zube et al. 1982; Smardon 2016; Gobster et al. 2019). An essential element in the urban planning and design toolbox is visual assessment of the landscape. Gobster et al. (2019) provide a clear and concise summary of the historical development and future paths of visual assessment, discussing concepts in visual quality assessment (VQA), visual impact assessment (VIA), and integration of visual-aesthetic values in multi-resource assessments. In particular, Gobster et al. (2019) note the distinction between VQA and VIA whereby VIA is generally more individual project specific with a focus on the application of regulatory tools, while VQA considers larger areas, over a long term planning horizon, and as such may have different methodological issues and approaches. Ak (2013) believes that VQA must assess the "visual characteristics, locational installation, and social life of a place (including all sense organs...) within a functional relationship," while Smardon (2016) remarks that VIA would be used as part of an environmental impact assessment (EIA) to evaluate project impact on landscape aesthetics. In summary, Zube et al. (1982) note that: 
Inquiry centered on the landscape itself is most strongly motivated by the pragmatic concerns of environmental management, planning, or design. The main concern here is the identification of intrinsic aesthetic qualities or elements of the landscape that can be stated objectively for use in decision making.

Zube et al. (1982) also explored the theoretical underpinnings of landscape perception and outlined four general paradigms that are summarized on the Planning side of Figure 8. The Engineering side of Figure 8, which summarizes contrasting paradigms of engineering, will be discussed in the next section. Further to Figure 8:

1 The Expert paradigm engages the evaluation of landscape quality through skilled and trained experts. Because historically this has been a subjective or quasi-quantitative evaluation, questions of rating scale reproducibility have been examined and for some of the more connotative attributes, there is concern (Palmer 2000; Sevenant and Antrop 2011; Smardon 2016). With increasing emphasis on participatory planning approaches, this challenge can become more complicated by the inclusion of non-expert assessment, although methods are being developed to address these issues (e.g. MacFarlane et al. 2005; Ives et al. 2017).

2 The Psychophysical paradigm is interesting and generally considers how scenery is viewed as a construct of the mind. In particular, Zube et al. (1982) discuss the psychobiological approach known as sentics "which postulates that the neural patterns of emotion have characteristic shapes within the brain. The shapes can be recognized in similar shapes on the landscape, leading to similar emotional responses." This concept has direct parallels with machine learning, or artificial intelligence analytical approaches, such as artificial neural networks (ANN) and adaptive neuro fuzzy inference systems (ANFIS) in modeling environmental systems (Ji et al. 2017; Khadr and Elshemy 2017).

3 The Cognitive paradigm considers information that is absorbed by an individual and is integrated with their past experience, future expectations, and sociocultural conditioning, which lends meaning to the landscape. The sociocultural conditioning concept indicates that there may be differences in landscape perceptions for different groups within and between regions (Scott et al. 2009; Cassatella 2011; Singh 2013) and, as noted above, this may lead to different planning practices in the East and in the West, for example.

4 The Experiential paradigm takes, essentially, a geographic lens in which landscape values are based on human-environment interaction (Zube et al. 1982).

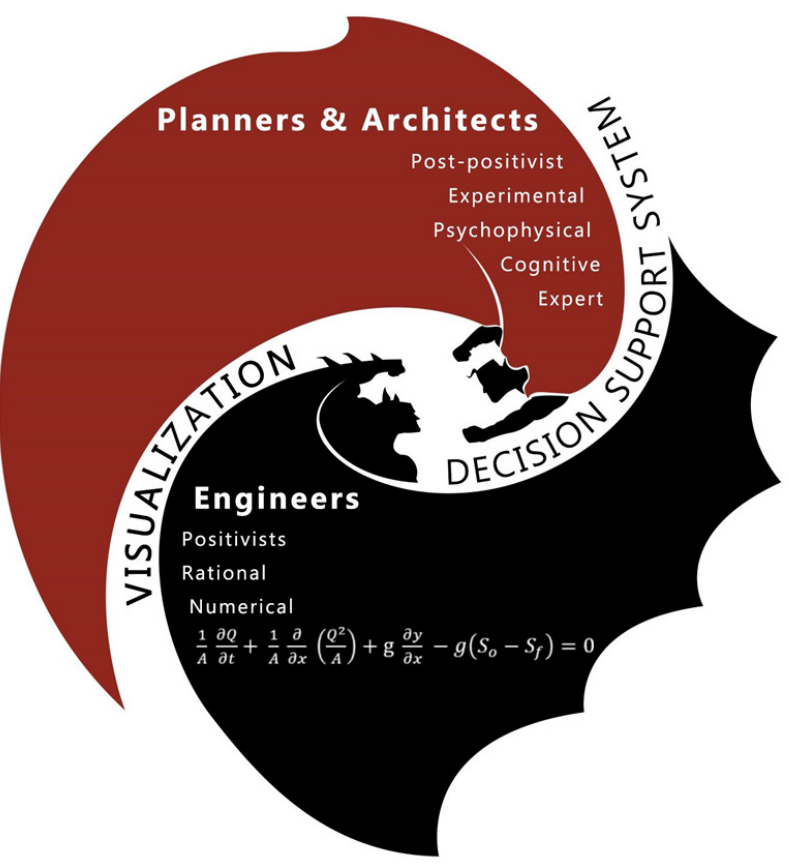

Figure 8 Landscape perception paradigms of the planner and architect contrasted with those of the engineer; the figure represents the gap in our approach to the form and function of urban green space planning, but also suggests the gap can be bridged by $3 \mathrm{D}$ visualization within an innovative decision support system.

The theoretical underpinnings in landscape architecture, as described by Zube et al. (1982), were historically put into practice through expert judgement, often using photomontages (e.g. Smardon 1988, 2016; Grahn and Stigsdotter 2010) that included assessments of shape, color, scale and texture. With the increasing sophistication of computing power, however, visualizations have progressed to 2D representations of space using GIS (Bishop 2003; Van Herzele and Wiedemann 2003; Pettit et al. 2006; Ives et al. 2017), 3D, and virtual reality representations (Bishop 2003; Pettit et al. 2006; Fisher-Gewirtzman 2012; Yokoya et al. 2014; Portman et al. 2015; Li et al. 2015; Velarde et al. 2017; Echevarria Sanchez et al. 2017). Mixed method approaches using questionnaires, semi-structured surveys, indicators, and multivariate analyses such as analytic hierarchy process (AHP) and principal component analysis also are being applied with increasing frequency (Van Herzele and Wiedemann 2003; Bulut and Yilmaz 2009; Hoyle et al. 2017; Meri and Lian 2017). Buscher (2006) documented the pro-cess of field assessment in landscape architecture, noting that ob-servation of landscape character or sense of place was essential. We will return to this issue, which we call familiarity, at the end of this paper. Buscher (2006) also describes the process of instructed seeing in which receptors (landscape elements or resources that a proposed development will affect directly or indirectly); sensi-tivity (the susceptibility of receptors to change); capacity (the degree of change the receptor can absorb); magnitude (the scale of change); and significance 
(judgement based) are assessed by individuals or collaboratively as group efforts.

\section{Dynamic Modeling and the Challenges of Visioning Space}

Use of dynamic mathematical models for water resource planning and management has become common engineering practice (Olsen et al. 2000; Loucks et al. 2005; Ambrose et al. 2009; Ziemińska-Stolarska and Skrzypski 2012; Wu et al. 2013; Willuweit and O'Sullivan 2013), but is implemented less so by urban planners and architects who may be tasked with developing a green space plan. In these applications, we specifically refer to deterministic, conceptual models rather than black boxes, or artificial intelligence (machine learning) modeling. A principal difference between deterministic modeling approaches and machine learning is that deterministic modeling enables the study team to evaluate What if? design scenarios because physical processes are explicitly represented.

In part, the differences between the engineering and planning and the architect visioning of the same project represent the challenge of multidisciplinary collaboration that is well illustrated by our recent work in Cha am, Thailand. Cha am is a small coastal resort town located on the Gulf of Thailand, approximately 175 $\mathrm{km}$ southwest of Bangkok. The town has $7 \mathrm{~km}$ of uninterrupted public beach and is a popular but not overly crowded or developed tourist destination. However, gated communities and condominiums are beginning to spring up. How will this new development impact stormwater and wastewater treatment infrastructure? is the question that was investigated over a $2 \mathrm{y}$ period in wastewater and collection system design classes at the Asian Institute of Technology (AIT), in Masters student research in Environmental Engineering at Mahidol University, and in a studio class for landscape architecture undergraduate (year 3) students at Thammasat University.

The existing drainage for Cha am is a combined sewer that discharges to an aerated lagoon treatment system with four ponds: aeration pond; settling pond; extended aeration pond; and evaporation pond (which was part of an original wetland system in this area). PCSWMM (the desktop computer version of the Stormwater Management Model) was used to model the collection and treatment pond systems. PCSWMM has been used extensively on projects in North America, Europe, and Australia (https://www.chijournal.org/) and it is increasingly being used in Southeast Asia (Sothea et al. 2010; Chaosakul et al. 2013; Shrestha et al. 2014; Irvine et al. 2014, 2015b; Loc et al. 2015; Nguyen et al., 2019). Schematic representations of the collection and pond systems are shown in Figures 9 and 10, with the original PCSWMM modeling being conducted by Mahidol University graduate students (Htun et al. 2016; Bhowmick et al. 2017). An example of the model calibration results for the existing collection system and the aeration lagoon is shown in Figure 11.

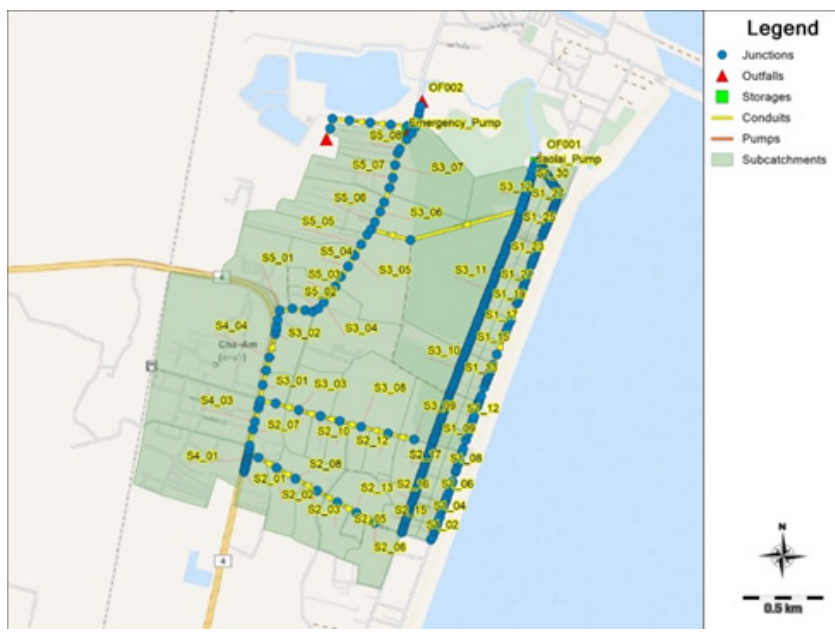

Figure 9 Representation of Cha am collection system in PCSWMM.
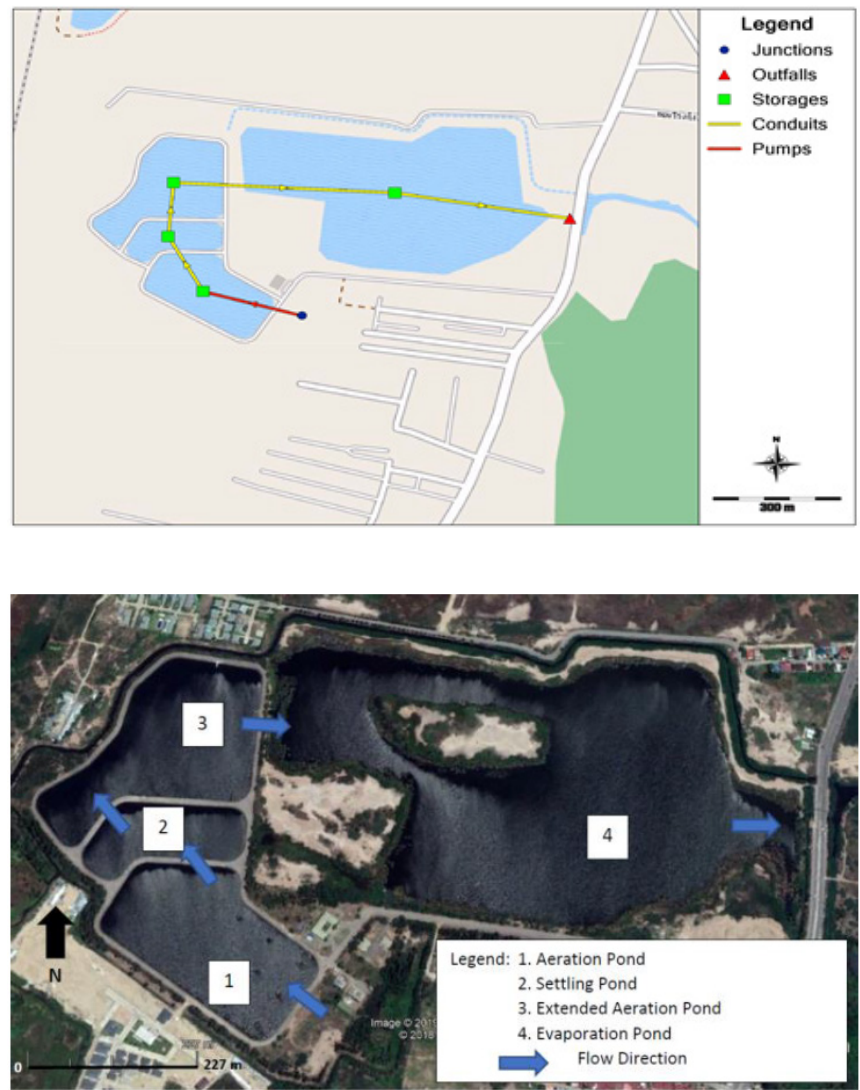

Figure 10 (upper) Representation of Cha am aerated lagoon system in PCSWMM (as a series of connected storage nodes) and (lower) a satellite image of the aerated lagoon system. 


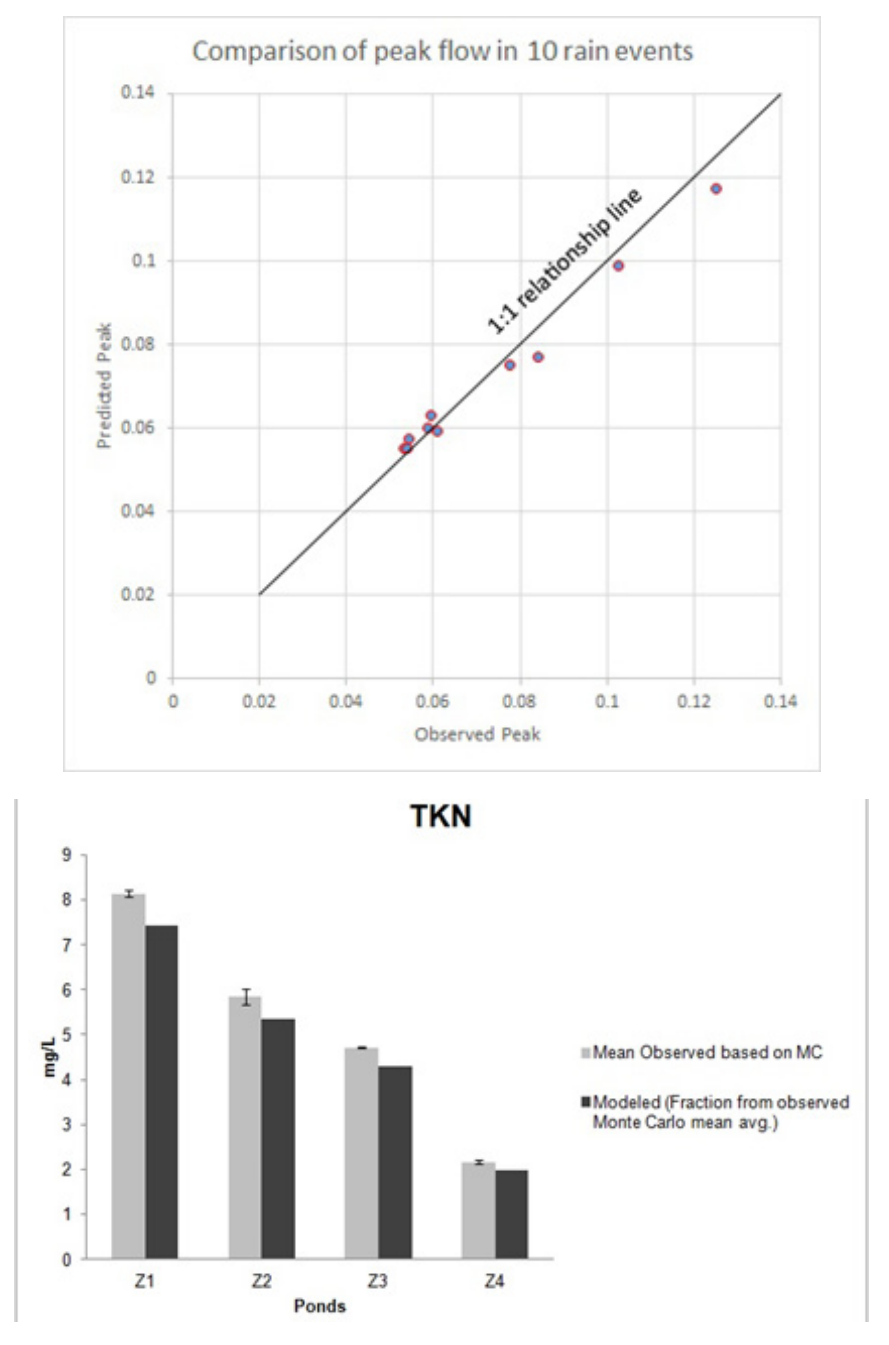

Figure 11 (upper) Comparison of observed vs modeled runoff event peak flows for the collection system $\left(\mathrm{m}^{3} / \mathrm{s}\right.$; from Htun et al. 2016); and (lower) observed vs modelled mean values of TKN in the aerated lagoon system (from Bhowmick et al. 2017).

The visioning of the drainage plan within the PCSWMM model is quite straightforward for the engineer. We typically need to accommodate a design storm of specified size and based on objective information related to surface and soil characteristics, a pipe network with appropriate dimensions and slopes can be determined, as we see in Figure 9. In other words, we have a traditional hard engineering design. The modeling becomes somewhat more complicated when significant green space is included in the design. This is particularly important in Singapore, for example, where soil throughflow seepage (rainfall derived inflow and infiltration) may impact the drain hydrograph. Irvine and Chua (2016) demonstrated, however, that PCSWMM can accurately model park hydrology using a unit hydrograph approach to represent soil throughflow. Should we wish to include WSUD in the design, the visioning process for the engineer using PCSWMM is shown in Figure 12.

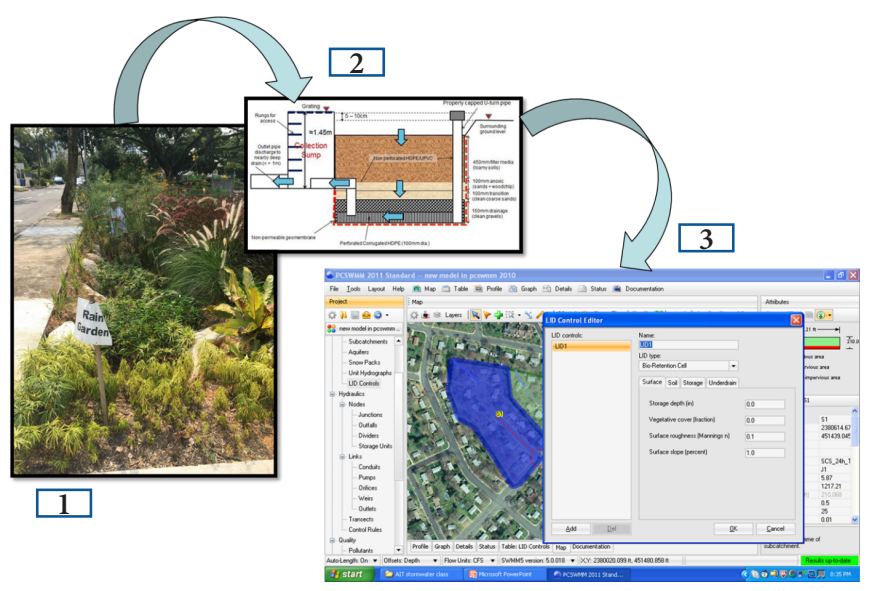

Figure 12 The steps in modeling the performance of a raingarden in PCSWMM. First, an existing, or planned, raingarden as it is envisioned in a neighbourhood (1) must have a set of designed infiltration substrates and (possibly) an underdrain (2); the engineering properties as shown in (2) are then used as input to the PCSWMM LID (WSUD) editor (3) to mathematically represent the flow processes associated with the raingarden.

Given the modeled performance of the existing system (Figure 11), the AIT engineering students were asked to create three different possible development scenarios (one with maximum build-out density and two with different combinations of WSUD) and to assess the impact of the hydraulic loading on the aerated lagoon system. The students conducted 2 days of field investigation, including interviews with a Department of Forestry official and local residents. Representation of the modeled WSUD technologies in the reports primarily relied on photos obtained via the internet, although one group visualized their WSUD designs using the Sketch Up software package. The group tasked to develop a scenario that maximized population density (and thereby minimized green space) found that the greater runoff generated in this scenario could result in sewer surcharging and localized flooding for a $24 \mathrm{~h} 2$ y $(120 \mathrm{~mm})$ design storm. One of the groups found that by including WSUD technologies, such as forest conservation, rainwater harvesting, permeable pavement, green roof, bioswales and planter boxes, they were able to reduce runoff volume by between $40 \%$ and $90 \%$ for individual subcatchment areas.

At the same time, students from the Thammasat University design studio class were asked to consider WSUD scenarios, an example of which is shown in Figure 13. Both the Thammasat students and the AIT students were provided with the same lecture material on the background to the problem, but while they clearly took quite different disciplinary approaches to addressing the project, there also were some commonalities. In particular, both groups conducted onsite visits to become familiar with the project area. In a more recent smart city study, we took what we believe to be a better integration approach whereby the year 
3 landscape architecture students developed three WSUD designs that included ponds, a natural wetland, and a vertical flow wetland for an area north of Bangkok. The landscape students subsequently met with the AIT engineering students at the study site, discussed their design vision and reviewed the site with the engineering students. The AIT students were then asked to model the designs using PCSWMM and assess feasibility, performance and cost. This study is ongoing and results will be reported elsewhere.
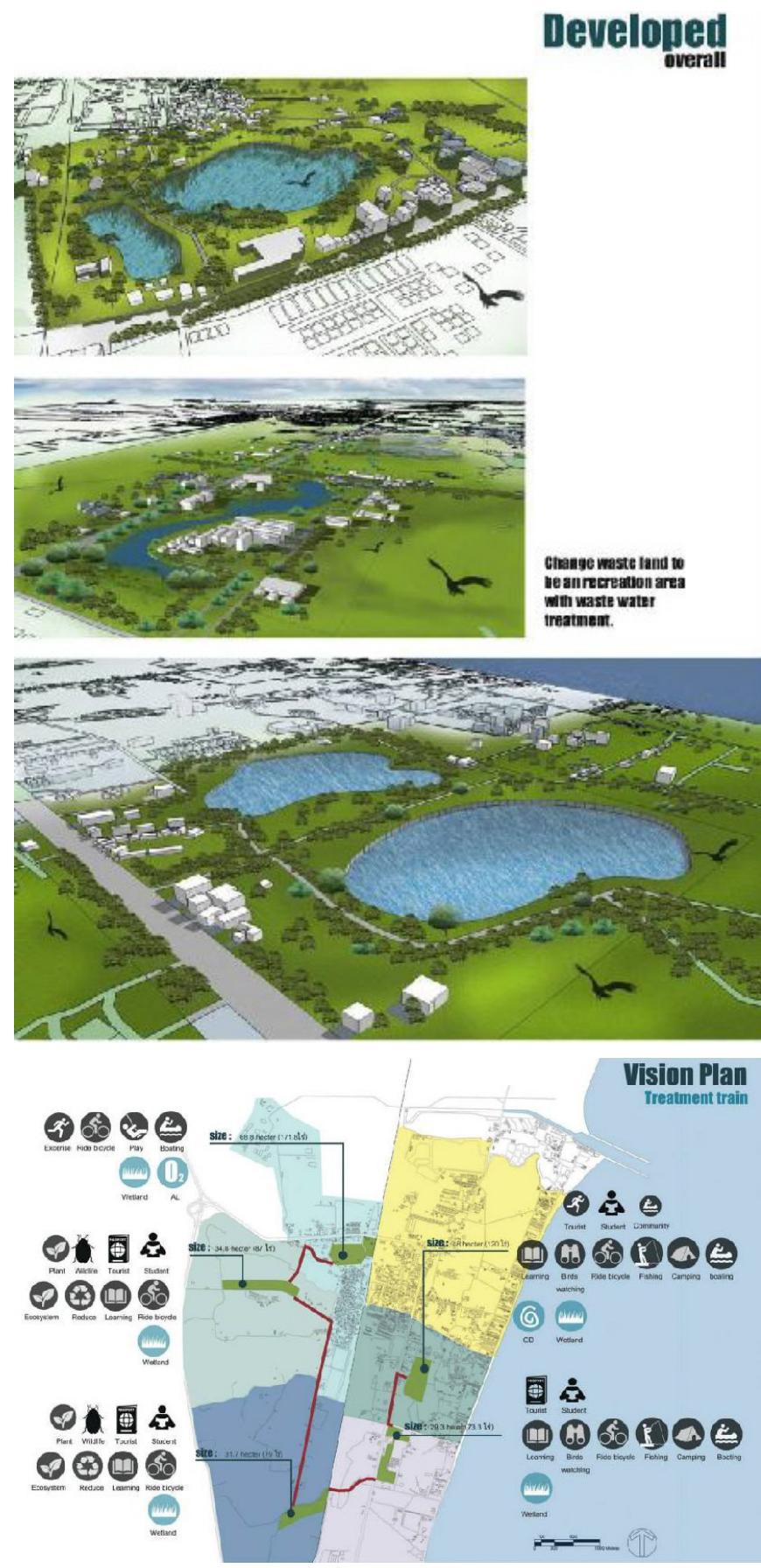

Figure 13 Thammasat University design studio example of development visioning for Cha am.
The challenge, as we see it, is to facilitate the planning and architectural use of dynamic models to help optimize efficiency of effort in developing competing green space scenarios or visions. The modeling efforts in Figures 9 and 12 are decidedly 2D visualizations, but Pettit et al. (2006) have noted that decision-makers and the participatory public often struggle to convert a $2 \mathrm{D}$ view into a 3D mental image. For green space considerations as part of urban flood management, one option is to include 3D visualization of the streetscape and waterscape within PCSWMM. An example of this type of approach that we are currently implementing is shown for an area of Phnom Penh, Cambodia (Figures 14-15). This area has been modeled previously (Sothea et al. 2010; Irvine et al. 2015b) and it is known to experience surface flooding. Here we used the model to explore impacts of a $100 \mathrm{~mm} 6 \mathrm{~h}$ design storm. The area of focus in Figures 14-15 includes an open combined sewage interceptor along Street 105 that discharges to the Boeng Cheung Ek wetland (discussed above) for treatment. Figure 14 shows the open sewer in the vicinity of the modeled area visualized in Figure 15. Figure 15 shows a progression of the 2D representation of the flooded area in PCSWMM, the modeled sewer profile and event hydrographs (which are standard engineering representations of urban flooding), and a 3D PCSWMM projection of the 2D model results that takes advantage of Google Streetscape. Following the findings reported by Pettit et al. (2006), planners, decision makers and the general public may have difficulty producing a mental image of flooding from Figures 15a-15c, but Figure 15d clearly illustrates flood conditions as they might impact local, informal housing. The visual representation in Figure $15 \mathrm{~d}$ is somewhat coarse spatially and we are currently working to smooth this projection. The 3D hydrologic representations may help planners and architects better interpret the location and depth of flooding problems, for example, since planners and architects are already using 3D visualizations in virtual cities (e.g. Virtual Singapore, https://www.nrf. gov.sg/programmes/virtual-singapore).

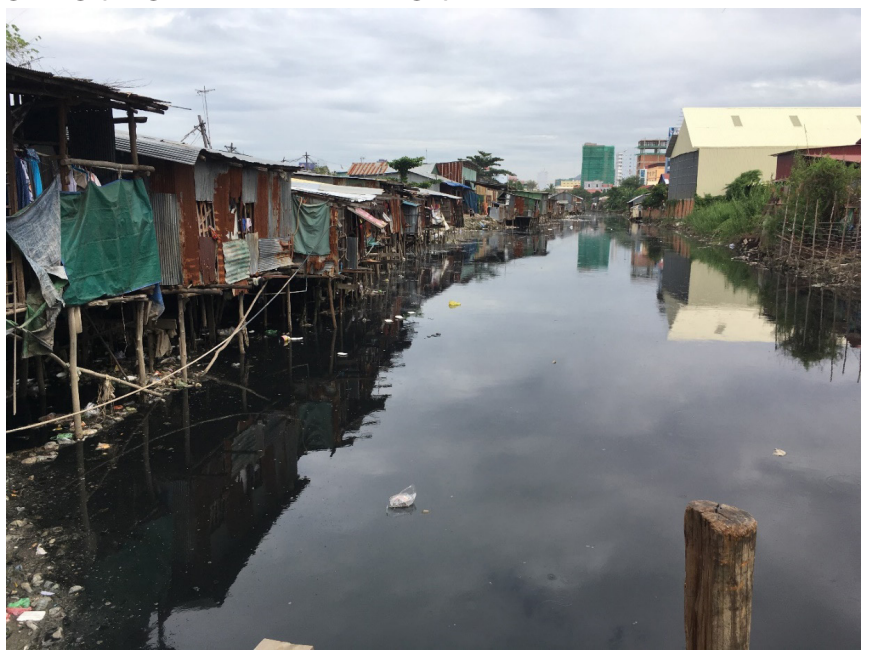

Figure 14 Interceptor sewer as it appears towards the end of St. 105 in the general study area (photo by authors). 

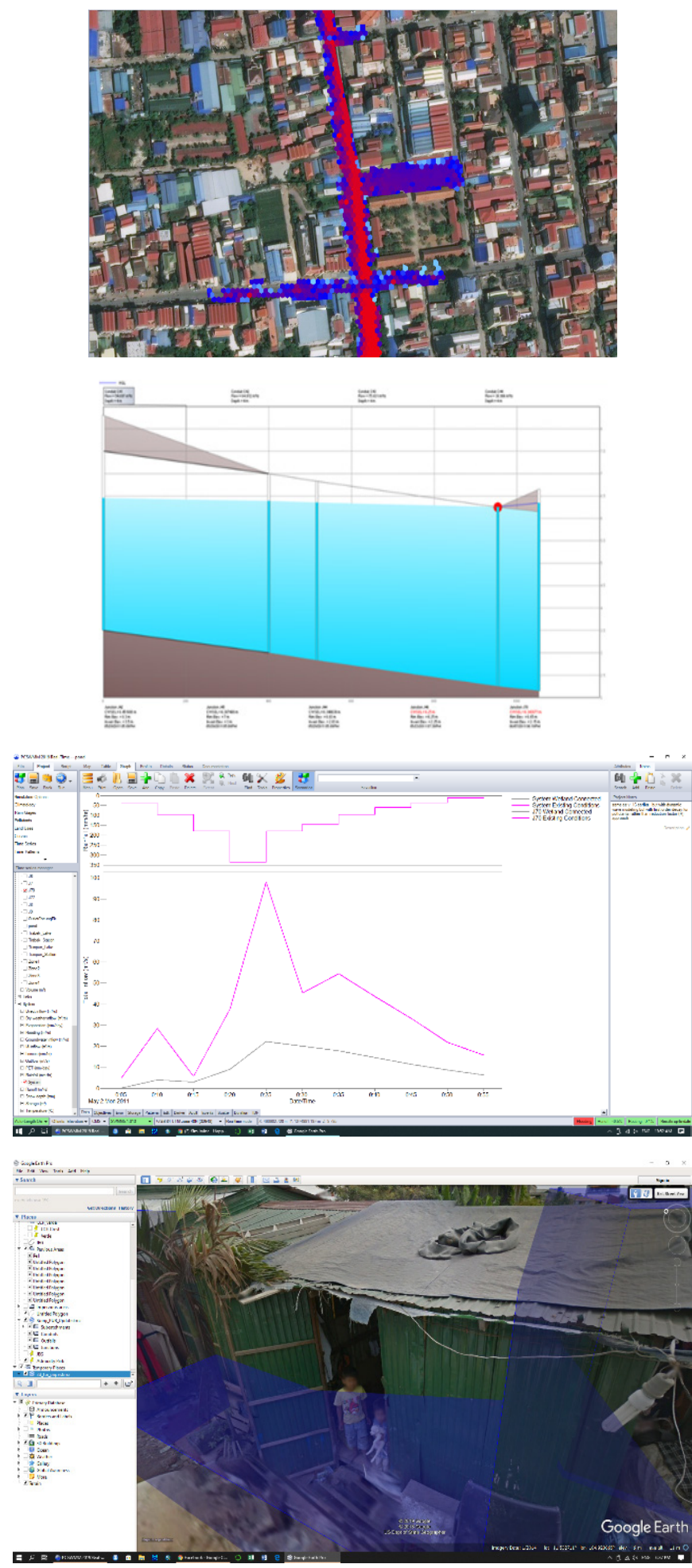

Figure 15 (top, a) 2D representation of flooding along St. 105 projected in Google Earth for a $6 \mathrm{~h} 100 \mathrm{~mm}$ design storm; (upper centre, b) Typical 1D engineering flow profile visualization for one section of the interceptor sewer along St. 105; the red circle indicates an area of surface flooding; (lower centre, c) hyetograph (above) and hydrographs (below) for two scenarios at one node in the interceptor sewer along St. 105 (bottom, d); the scenario analysis shows that storage of runoff in the wetland reduces peak flow and event volume, and eliminates surface flooding in the area of informal housing; (bottom, d) 3D visualization of 2D flood model in PCSWMM projected in Google Streetscape, clearly illustrating flood risk.

An $81000 \mathrm{~m}^{2}$ natural wetland still exists in the study area (Figure 16) and in an additional modeling exercise the interceptor sewer flow was directly connected to the wetland as a type of inline treatment and storage unit (with an assumed depth of 1 $\mathrm{m})$. Figure $15 \mathrm{c}$ clearly shows that the optimized use of the natural green space (wetland) reduced peak event flow and eliminated surface flooding for the design storm.

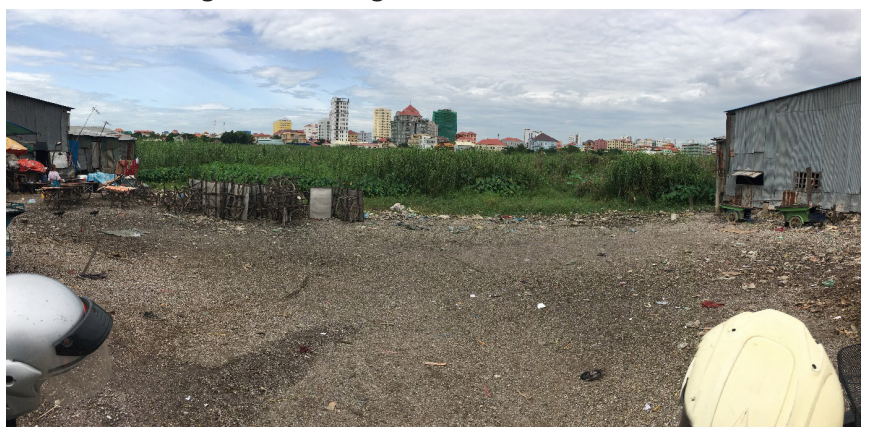

Figure 16 The natural wetland included in the PCSWMM model for enhanced combined sewer storage under the design storm scenario.

We must consider how a dynamic mathematical modeling approach can be made more accessible to nonspecialists in communicating urban design. Silva-Hidalgo et al. (2009) examined the issue of modeling for integrated water resources management (IWRM) and suggested that while mathematical models can be valuable tools, in addition to hydrology, new models needed to be developed to include social, economic, legal and environmental considerations. Too often it was felt that models provided a theoretical rather than a practical solution for planning and frequently models were not accepted or understood by nonexperts. Serrat-Capdevila et al. (2011) stated that "In general, scientists, academicians and some practitioners are convinced that numerical models are indeed a good tool to support decision-making, but the reality is that the adoption of modeling tools by policy makers and decision makers is not standard practice."

To conclude this section, we suggest revisiting Figure 8 to summarize the challenges of integrating urban planning and architecture with engineering visioning of urban green space form and function. It is important to bridge the gap between engineering and planning and architectural practices, and we feel that an innovative decision support system which includes 3D visualization and ecosystem service evaluations could also facilitate the communication of planning and design options to the com- 
munity. Some work in relation to urban green infrastructure has been done (e.g. Jayasooriya and $\mathrm{Ng}$ 2013; Fan and Matsumoto 2019), but a seamless tool that includes fully dynamic hydrologic-hydraulic modeling remains elusive. Furthermore, in their recent review Kuller et al. (2017) concluded "Although ecosystem services have been linked to water in the urban environment ... a coherent, spatially explicit framework linking ecosystem services to urban planning and WSUD is absent in the literature."

\section{Conclusion}

We believe that well-planned urban green space can enhance the liveability, resiliency, and sustainability of our cities. As a postscript, subsequent to the completion of the initial draft of this paper, the COVID-19 pandemic resulted in the global disruption of economies, travel, space and social interaction, and tragic loss of life. It also quickly catalysed conversations about the new normal and the opportunity to reset society in many sectors, including the implications for landscape architects and landscape design. One view suggests that green space design should be more expansive and perhaps more connected to accommodate safe social distancing for a variety of community events (Greenwald 2020, https://www.metropolismag.com/architecture/landscape/covid-19-landscape-architecture/, accessed 2020-07-10). Another view is that there will be a greater demand for smaller decentralized green spaces or neighbourhood parks that can support community wellbeing under stay at home orders (Honey-Roses et al. 2020). In either case, green space should continue to play a central role in planning for community wellbeing and water management

We have discussed different modeling techniques, including ecosystem services monetization and indices and dynamic hydrologic-hydraulic modeling that can be useful decision support tools for urban planners and architects. However, challenges remain to mainstreaming these tools in a collaborative, multidisciplinary environment. We have suggested that the path forward to overcome some of the challenges related to dynamic modeling application in the urban planning arena is through development of 3D visualization and implementation of expert systems for scenario analysis. A mixed method approach to ecosystem services valuation that considers monetization and multicriteria analysis in a spatially-explicit framework may be a productive path forward. Ultimately, in making planning decisions about green space, it would be helpful to develop a full decision support system package that would link ecosystem services assessment and physical environment models such as PCSWMM. Our team is currently working on such a system.

Finally, we would caution that while models can be useful decision support tools, it is essential that the planners and engineers establish familiarity with their project area. A valued friend, eminent ecologist and UN Global 500 Laureate, Dr. D. Ghosh, always emphasized the importance of familiarity (Ghosh 2016) and we were reminded of this issue in one of our recent projects in Ho Chi Minh City (Loc et al. 2015). The PCSWMM model results showed that green roof implementation could be effective in reducing flooding in the Nhieu Loc-Thi Nghe Basin area. However, interviews with 140 households in the area overwhelmingly indicated that green roofs were not an acceptable management option. Thus other alternatives would need to be considered in order for a project to be successful, or an education program on green roofs would have to be developed.

\section{Acknowledgments}

Contributions by KNI and KDW to this paper were undertaken while both were on Bualuang ASEAN Fellowships at Thammasat University and the support is gratefully acknowledged.

\section{References}

Ak, M.K. 2013. "Visual Quality Assessment Methods in Landscape Architecture Studies." In Advances in Landscape Architecture. IntechOpen.

https://www.intechopen.com/books/advances-in-landscape-architecture

Ambrose, R.B. Jr, T.A. Wool, and T.O. Barnwell Jr. 2009. “Development of Water Quality Modeling in the United States." Environmental Engineering Research 14 (4): 200-10.

Ballas, D. 2013. “What Makes a 'Happy City'?” Cities 32: S39-50.

Bhowmick, A., K.N. Irvine, and R. Jindal. 2017. "Mathematical Modeling of Effluent Quality of Cha-Am Municipality Wastewater Treatment Pond System using PCSWMM." Journal of Water Management Modeling 25: C423 https://doi.org/10.14796/JWMM.C423

Bishop, I.D. 2003. “Assessment of Visual Qualities, Impacts, and Behaviours, in the Landscape, by Using Measures of Visibility." Environment and Planning B: Planning and Design 30 (5): 677-88.

Blumenfeld, H. 1949. "Theory of City Form, Past and Present." Journal of the Society of Architectural Historians 8 (3/4): 7-16.

Braat, L.C., and R. De Groot. 2012. "The Ecosystem Services Agenda: Bridging the Worlds of Natural Science and Economics, Conservation and Development, and Public and Private Policy." Ecosystem Services 1 (1): 4-15.

Brooks, J.S. 2013. “Avoiding the Limits to Growth: Gross National Happiness in Bhutan as a Model for Sustainable Development." Sustainability 5 (9): 3640-64.

Brown, L.J., D. Dixon, and O. Gillham. 2013. Urban Design for an Urban Century, Shaping More Livable, Equitable, and Resilient Cities, 2nd ed. New York: Wiley.

Bulut, Z., and H. Yilmaz. 2009. “Determination of Waterscape Beauties Through Visual Quality Assessment Method." Environmental Monitoring and Assessment 154 (1-4): 459.

Büscher, M. 2006. "Vision in Motion." Environment and Planning A 38 (2): 281-99.

Carson, R. 1962. Silent Spring. Boston: Houghton Mifflin Company. 
Carson, T.B., D.E. Marasco, P.J. Culligan, and W.R. McGillis. 2013. "Hydrological Performance of Extensive Green Roofs in New York City: Observations and Multi-Year Modeling of Three Full-Scale Systems." Environmental Research Letters 8 (2): 024036.

Cassatella, C. 2011. Assessing Visual and Social Perceptions of Landscape. In Landscape Indicators. Dordrecht: Springer.

Chang, Chew-Hung, Kim Irvine, Bing Sheng Wu, and Tricia Seow. 2018. "Reflecting on Field-Based and Technology-Enabled Learning in Geography." In Learning Geography Beyond the Traditional Classroom, edited by Chew-Hung Chang, Bing Sheng Wu, Tricia Seow, and Kim Irvine. Singapore: Springer.

Chaosakul, T., T. Koottatep, and K.N. Irvine. 2013. “Low Impact Development Modeling to Assess Localized Flood Reduction in Thailand." Journal of Water Management Modeling 21: R246-18. https://doi.org/10.14796/JWMM.R246-18.

Chiesura, A. 2004. “The Role of Urban Parks for the Sustainable City." Landscape and Urban Planning 68 (1): 129-38.

Christie, M., I. Fazey, R. Cooper, T. Hyde, and J.O. Kenter. 2012. “An Evaluation of Monetary and Non-Monetary Techniques for Assessing the Importance of Biodiversity and Ecosystem Services to People in Countries with Developing Economies." Ecological Economics 83: 67-78.

Clark, B. 2003. "Ebenezer Howard and the Marriage of Town and Country: An Introduction to Howard's Garden Cities of To-morrow (Selections)." Organization \& Environment 16 (1): 87-97.

Commoner, B., M. Corr, and P. Stamler. 1971. "The Causes of Pollution." Environment 13: 2-19.

Corlett, R.T. 1988. "Bukit Timah: The History and Significance of a Small Rain-Forest Reserve." Environmental Conservation 15 (1): 37-44.

Corlett, R.T. 1990. “Flora and Reproductive Phenology of the Rain Forest at Bukit Timah, Singapore." Journal of Tropical Ecology 6 (1): 55-63.

Costanza, R., R. d'Arge, R. De Groot, S. Farber, M. Grasso, B. Hannon, and R.G. Raskin. 1997. "The Value of the World's Ecosystem Services and Natural Capital." Nature 387 (6630): 253.

Costanza, R., R. de Groot, L. Braat, I. Kubiszewski, L. Fioramonti, P. Sutton, and M. Grasso. 2017. "Twenty Years of Ecosystem Services: How Far Have We Come and How Far Do We Still Need to Go?" Ecosystem Services 28: 1-16.

Crossman, N.D., Benjamin Burkhard, Stoyan Nedkov, Louise Willemen, Katalin Petz, Ignacio Palomo, Evangelia G. Drakou et al. 2013. "A Blueprint for Mapping and Modeling Ecosystem Services." Ecosystem Services 4: 4-14.

Cutter, S.L., L. Barnes, M. Berry, C. Burton, E. Evans, E. Tate, and J. Webb. 2008. "A Place-Based Model for Understanding Community Resilience to Natural Disasters." Global Environmental Change 18 (4): 598-606.

De Ridder, K., V. Adamec, A. Bañuelos, M. Bruse, M. Bürger, O. Damsgaard, and A. Thierry. 2004. “An Integrated
Methodology to Assess the Benefits of Urban Green Space." Science of the Total Environment 334: 489-97.

Echevarria Sanchez, G.M., T. Van Renterghem, K. Sun, B. De Coensel, and D. Botteldooren. 2017. "Using Virtual Reality for Assessing the Role of Noise in the Audio-Visual Design of an Urban Public Space." Landscape and Urban Planning 167: 98-107.

Ehrlich, P.R. 1971. The Population Bomb. New York: Ballantine Books.

Evans, D., and R. Fletcher. 2015. "The Landscape of Angkor Wat Redefined." Antiquity 89 (348): 1402-19.

Fan, X., and T. Matsumoto. 2019. "GIS-based Social Cost-Benefit Analysis on Integrated Urban Water Management in China: A Case Study of Sponge City in Harbin." Sustainability 11 (19): 5527.

Fisher-Gewirtzman, D. 2012."3D Models as a Platform for Urban Analysis and Studies on Human Perception of Space." Usage, Usability, and Utility of 3D City Models-European COST Action TU0801, 01001. https://doi.org/10.1051/TU0801/201400001

Fletcher, T.D., W. Shuster, W.F. Hunt, R. Ashley, D. Butler, S. Arthur, and P.S. Mikkelsen. 2015. “SUDS, LID, BMPs, WSUD and More-The Evolution and Application of Terminology Surrounding Urban Drainage." Urban Water Journal 12 (7): $525-42$.

Fukamachi, K., H. Oku, Y. Kumagai, and A. Shimomura. 2000. "Changes in Landscape Planning and Land Management in Arashiyama National Forest in Kyoto." Landscape and Urban Planning 52 (2-3): 73-87.

Fuller, R.A., K.N. Irvine, P. Devine-Wright, P.H. Warren, and K.J. Gaston. 2007. "Psychological Benefits of Greenspace Increase with Biodiversity." Biology Letters 3 (4): 390-4.

Gabriel, K.M., and W.R. Endlicher. 2011. “Urban and Rural Mortality Rates During Heat Waves in Berlin and Brandenburg, Germany." Environmental Pollution 159 (8-9): 2044-50.

Garrison, N., and K. Hobbs. 2011. Rooftops to Rivers Il: Green Strategies for Controlling Stormwater and Combined Sewer Overflows. New York: Natural Resources Defense Council.

Ghosh, D. 2016. "Revisiting East Kolkata Wetlands: Globality of the Locals." Journal of Geography, Environment and Earth Science International 5 (3): 1-14.

Gobster, P.H., R.G. Ribe, and J.F. Palmer. 2019. “Themes and Trends in Visual Assessment Research: Introduction to the Landscape and Urban Planning Special Collection on the Visual Assessment of Landscapes." Landscape and Urban Planning 191: 103635.

Gómez-Baggethun, E., and M. Ruiz-Pérez. 2011. “Economic Valuation and the Commodification of Ecosystem Services." Progress in Physical Geography 35 (5): 613-28.

Grahn, P., and U.K. Stigsdotter. 2010. “The Relation between Perceived Sensory Dimensions of Urban Green Space and 
Stress Restoration." Landscape and Urban Planning 94 (3-4): 264-75.

Gunawardena, K.R., M.J. Wells, and T. Kershaw. 2017. “Utilising Green and Blue Space to Mitigate Urban Heat Island Intensity." Science of the Total Environment 584: 1040-55.

Haase, D., N. Larondelle, E. Andersson, M. Artmann, S. Borgström, J. Breuste, E. Gomez-Baggethun et al. 2014. "A Quantitative Review of Urban Ecosystem Service Assessments: Concepts, Models, and Implementation." Ambio 43 (4): 413-33.

Hardin, G. 1968. "The Tragedy of the Commons." Science 162 (3859): 1243-8.

Hochegger, K. 1998. Farming Like the Forest. Traditional Home Garden Systems in Sri Lanka. Tropical Agroecology, vol. 191. Weikersheim: Margraf Verlag. https://edepot.wur.nl/429598

Honey-Rosés, J., I. Anguelovski, J. Bohigas, and M. Nieuwenhuijsen. 2020. "The Impact of COVID-19 on Public Space: A Review of the Emerging Questions." Researchgate pre-print. https://doi.org/10.31219/osf.io/rf7xa

Howard, E. 1902. Garden Cities of To-Morrow. London: Swan, Sonnenschein \& Co. Ltd.

Howett, C. 1998. "Ecological Values in Twentieth-Century Landscape Design: A History and Hermeneutics." Landscape Journal 17: 80-98.

Hoyle, H., J. Hitchmough, and A. Jorgensen. 2017. "All about the 'Wow Factor'? The Relationships between Aesthetics, Restorative Effect and Perceived Biodiversity in Designed Urban Planting." Landscape and Urban Planning 164: 109-23.

Htun, T., K.N. Irvine, and R. Jindal. 2016. “Mathematical Modeling of Wastewater Collection System in Cha Am Municipality using PCSWMM." International Journal of Advances in Agricultural and Environmental Engineering 3 (2): 409-13.

Irvine, K.N., B.H. Choy, J. Gaut, L.H.C. Chua, H.L. Ho, and N. Tontisirin. 2020. “Hedonic Pricing to Monetize Ecosystem Services Provided by Water Sensitive Urban Design: A Comparison of Singapore and Geelong, Australia." Nakhara: Journal of Environmental Design and Planning 19. https://ph01.tci-thaijo.org/index.php/nakhara/article/ view/241321/165763

Irvine, K.N., and L.H.C. Chua. 2016. “Modeling Stormwater Runoff from an Urban Park, Singapore, using PCSWWM." Journal of Water Management Modeling 24: C410. https://doi.org/10.14796/JWMM.C410.

Irvine, K.N., L.H.C. Chua, and H.S. Eikass. 2014. "The Four National Taps of Singapore: A Holistic Approach to Water Resources Management from Drainage to Drinking Water." Journal of Water Management Modeling 22: C375. https://doi.org/10.14796/JWMM.C375.

Irvine, K.N., T. Seow, K.W. Leong, and S.I.D. Cheong. 2015a. “How High's the Water, Mama? A Reflection on Water Resources
Education in Singapore." HSSE Online 4 (2): 128-62.

Irvine, K.N., C. Sovann, S. Suthipong, S. Kok, and E. Chea. 2015b.

"Application of PCSWMM to Assess Wastewater Treatment and Urban Flooding Scenarios in Phnom Penh, Cambodia: A Tool to Support Eco-City Planning." Journal of Water Management Modeling 23: C389. https://doi.org/10.14796/JWMM.C389.

Ives, C.D., C. Oke, A. Hehir, A. Gordon, Y. Wang, and S.A. Bekessy. 2017. “Capturing Residents' Values for Urban Green Space: Mapping, Analysis and Guidance for Practice." Landscape and Urban Planning 161: 32-43.

Iwatsuki, K. 2009. “Harmonious Co-existence between Nature and Mankind: An Ideal Lifestyle for Sustainability Carried Out in the Traditional Japanese Spirit." Humans and Nature 19: 1-18.

Jayasooriya, V., and A.W. Ng. 2013. Development of a Framework for the Valuation of Eco-System Services of Green Infrastructure. In 20th International Congress on Modeling and Simulation, Adelaide, Australia.

Ji, X., X. Shang, R.A. Dahlgren, and M. Zhang. 2017. “Prediction of Dissolved Oxygen Concentration in Hypoxic River Systems using Support Vector Machine: A Case Study of Wen-Rui Tang River, China." Environmental Science and Pollution Research. https://doi.org/10.1007/s11356-017-9243-7

Jiang, Y., C. Zevenbergen, and Y. Ma. 2018. “Urban Pluvial Flooding and Stormwater Management: A Contemporary Review of China's Challenges and 'Sponge Cities' Strategy." Environmental Science \& Policy 80: 132-43.

Jones, K.R. 2018. "'The Lungs of the City': Green Space, Public Health and Bodily Metaphor in the Landscape of Urban Park History." Environment and History 24 (1): 39-58.

Kelemen, E., M. García-Llorente, G. Pataki, B. Martín-López, and E. Gómez-Baggethun. 2014. Non-monetary Techniques for the Valuation of Ecosystem Service. ECNC-European Centre for Nature Conservation. OpenNESS Reference Book EC FP7.

Kenworthy, J.R. 2006. "The Eco-City: Ten Key Transport and Planning Dimensions for Sustainable City Development." Environment and Urbanization 18 (1): 67-85.

Khadr, M., and M. Elshemy. 2017. “Data-driven Modeling for Water Quality Prediction Case Study: The Drains System Associated with Manzala Lake, Egypt." Ain Shams Engineering Journal. https://doi.org/10.1016/j.asej.2016.08.004

Kok, K.H., L. Mohd Sidek, M.F. Chow, M.R. Zainal Abidin, H. Basri, and G. Hayder. 2016. "Evaluation of Green Roof Performances for Urban Stormwater Quantity and Quality Controls." International Journal of River Basin Management 14 (1): 1-7.

Kremer, P., Z.A. Hamstead, and T. McPhearson. 2016. “The Value of Urban Ecosystem Services in New York City: A Spatially 
Explicit Multicriteria Analysis of Landscape Scale Valuation Scenarios." Environmental Science \& Policy 62: 57-68.

Kuller, M., P.M. Bach, D. Ramirez-Lovering, and A. Deletic. 2017. "Framing Water Sensitive Urban Design as Part of the Urban Form: A Critical Review of Tools for Best Planning Practice." Environmental Modeling \& Software 96: 265-82.

Laaidi, K., A. Zeghnoun, B. Dousset, P. Bretin, S. Vandentorren, E. Giraudet, and P. Beaudeau. 2011. "The Impact of Heat Islands on Mortality in Paris during the August 2003 Heat Wave." Environmental Health Perspectives 120 (2): 254-59.

Lashford, C., M. Rubinato, Y. Cai, J. Hou, S. Abolfathi, S. Coupe, and S. Tait. 2019. “SuDS \& Sponge Cities: A Comparative Analysis of the Implementation of Pluvial Flood Management in the UK and China." Sustainability 11 (1): 213.

Lee, A.C., and R. Maheswaran. 2011. "The Health Benefits of Urban Green Spaces: A Review of the Evidence." Journal of Public Health 33 (2): 212-22.

Levin, R., M.J. Brown, M.E. Kashtock, D.E. Jacobs, E.A. Whelan, J. Rodman, and T. Sinks. 2008. "Lead Exposures in US Children 2008: Implications for Prevention." Environmental Health Perspectives 116 (10): 1285-93.

Li, X., C. Zhang, W. Li, R. Ricard, Q. Meng, and W. Zhang. 2015. “Assessing Street-Level Urban Greenery Using Google Street View and a Modified Green View Index." Urban Forestry \& Urban Greening 14 (3): 675-85.

Lim, H.S., and X.X. Lu. 2016. “Sustainable Urban Stormwater Management in the Tropics: An Evaluation of Singapore's ABC Waters Program." Journal of Hydrology 538: 842-62.

Loc, H.H., M.S. Babel, S. Weesakul, K.N. Irvine, and M.D. Pham. 2015. “Exploratory Assessment of SUDS Feasibility in Nhieu Loc-Thi Nghe Basin, Ho Chi Minh City, Vietnam." British Journal of Environment \& Climate Change 5 (2): 91-103.

Loc, H.H., T.J. Ballatore, K.N. Irvine, T.H.D. Nguyen, T.C.T. Truong, and Y. Shimizu. 2018a. "Socio-geographic Indicators to Evaluate Landscape Cultural Ecosystem Services: A Case of Mekong Delta, Vietnam." Ecosystem Services 31: 527-542.

Loc, H.H., K.N. Irvine, N.T.H. Diep, N.T.K. Quyen, N.N. Tue, and Y. Shimizu. 2018b. "The Legal Aspects of Ecosystem Services in Agricultural Land Pricing, Some Implications from a Case Study in Vietnam's Mekong Delta. Ecosystem Services 29: 360-9.

Loc, H.H., K.N. Irvine, A. Suwanarit, P. Vallikul, F. Likitswat, A. Sahavacharin, C. Sovann, and S.H. Le. 2020. "Mainstreaming Ecosystem Services as Public Policy in South East Asia, From Theory to Practice." In Sustainability and Law. Cham: Springer.

Loomis, J., P. Kent, L. Strange, K. Fausch, and A. Covich. 2000. "Measuring the Total Economic Value of Restoring Ecosystem Services in an Impaired River Basin: Results from a Contingent Valuation Survey." Ecological Economics 33 (1): 103-17.
Loucks, D.P., E. Van Beek, J.R. Stedinger, J.P. Dijkman, and M.T. Villars. 2005. Water Resources Systems Planning and Management: An Introduction to Methods, Models and Applications. Paris: UNESCO.

Lowenthal, D., and H.C. Prince. 1965. "English Landscape Tastes." Geographical Review 55 (2): 186-22.

Lupp, G., B. Förster, V. Kantelberg, T. Markmann, J. Naumann, C. Honert, M. Koch, and S. Pauleit. 2016. "Assessing the Recreation Value of Urban Woodland Using The Ecosystem Service Approach in Two Forests in the Munich Metropolitan Region." Sustainability 8 (11): 1156.

MA (Millennium Ecosystem Assessment). 2005. Ecosystems and Human Wellbeing: Synthesis. Washington, DC: Island Press.

Maas, J., R.A. Verheij, P.P. Groenewegen, S. De Vries, and P. Spreeuwenberg. 2006. “Green Space, Urbanity, and Health: How Strong Is the Relation?" Journal of Epidemiology \& Community Health 60 (7): 587-92.

MacFarlane, R., H. Stagg, K. Turner, and M. Lievesley. 2005. “Peering through the Smoke? Tensions in Landscape Visualisation." Computers, Environment and Urban Systems 29 (3): 341-59.

Marsalek, J., and H. Schreier. 2009. "Innovation in Stormwater Management in Canada: The Way Forward." Water Quality Research Journal of Canada 44 (1): v-x.

Marsh, W.M. 1991. Landscape Planning Environmental Applications, 2nded. Wiley, New York.

Martín-López, B, I. Iniesta-Arandia, M. García-Llorente, I. Palomo, I. Casado-Arzuaga, D. García Del Amo, E. Gómez-Baggethun et al. 2012. “Uncovering Ecosystem Service Bundles through Social Preferences." PLoS one 7 (6): e38970.

McHarg, I.L., and L. Mumford. 1969. Design with Nature. New York: American Museum of Natural History.

McPherson, E.G. 1992. "Accounting for Benefits and Costs of Urban Greenspace." Landscape and Urban Planning 22 (1): 41-51.

Meadows, D.H., D.L. Meadows, J. Randers, and W.W. Behrens. 1972. The Limits to Growth. New York: Penguin.

Mekala, G.D., R.N. Jones and D. Hatton MacDonald. 2015. “Valuing the Benefits of Creek Rehabilitation: Building a Business Case for Public Investments in Urban Green Infrastructure." Environmental Management 55 (6): 1354-65.

Meri, J., and L. Lian. 2017. "A Mixed Methods Approach to Urban Ecosystem Services: Experienced Environmental Quality and Its Role in Ecosystem Assessment Within an InnerCity Estate." Landscape and Urban Planning 161: 10-21.

MEWR (Ministry of Environment and Water Resources). 2018. Opening address by Dr Amy Khor, senior minister of state for the environment and water resources at the seminar on "active, beautiful, clean waters - towards resilience, liveability and sustainability in design".

https://www.mewr.gov.sg/news/opening-address-by-dramy-khor--senior-minister-of-state-for-the-environmentand-water-resources-at-the-seminar-on-active--beautiful- 
-clean-waters--towards-resilience--liveability-and-sustainability-in-design-on-11-jul-2018

Miao, P., ed. (2013). Public Places in Asia Pacific Cities: Current Issues and Strategies (Vol. 60). Springer Science \& Business Media.

Michalos, A.C., B. Smale, R. Labonté, N. Muharjarine, K. Scott, K. Moore, and P. Graham. 2011. The Canadian Index of Well-being: Technical Report 1.0. Waterloo, Ontario: Canadian Index of Wellbeing.

Millward, A.A., and S. Sabir. 2011. “Benefits of a Forested Urban Park: What is the Value of Allan Gardens to the City of Toronto, Canada?" Landscape and Urban Planning 100 (3): 177-88.

Molyvann, V. 2003. Modern Khmer Cities. Cambodia: Reyum Publishing.

Morison, P.J., and R.R. Brown. 2011. “Understanding the Nature of Publics and Local Policy Commitment to Water Sensitive Urban Design." Landscape and Urban Planning 99 (2): 83-92.

Murphy, D., S. Morgan, S. Celik, and B. Retzlaff. 2018. “Evaluation of a Residential Green Roof System for Stormwater Runoff Retention." Journal of Living Architecture 5 (1): 16-30.

$\mathrm{Ng}$, Y.X.Y. 2015. "A Study of Urban Heat Island using 'Local Climate Zones' - The Case of Singapore." British Journal of Environment and Climate Change 5 (2): 116-33.

Nguyen, H.Q., M. Radhakrishnan, T.K.N. Bui, D.D. Tran, L.P. Ho, V.T. Tong et al. 2019. “Evaluation of Retrofitting Responses to Urban Flood Risk in Ho Chi Minh City using the Motivation and Ability (MOTA) Framework." Sustainable Cities and Society 47: 101465.

Northridge, M.E., E.D. Sclar, and P. Biswas. 2003. "Sorting Out the Connections Between the Built Environment and Health: A Conceptual Framework for Navigating Pathways and Planning Healthy Cities." Journal of Urban Health 80 (4): 556-68.

O'Brien, C. 2008. "Sustainable Happiness: How Happiness Studies Can Contribute to a More Sustainable Future." Canadian Psychology/Psychologie Canadienne 49 (4): 289.

Olsen, J.R., P.A. Beling, and J.H. Lambert. 2000. “Dynamic Models for Floodplain Management." Journal of Water Resources Planning and Management 126 (3): 167-75.

Palmer, J.F. 2000. “Reliability of Rating Visible Landscape Qualities.” Landscape Journal 19 (1-2): 166-78.

Park, J., D. Lee, C. Park, H. Kim, T. Jung, and S. Kim. 2017. “Park Accessibility Impacts Housing Prices in Seoul." Sustainability 9 (2): 185.

Pettit, C.J., W. Cartwright, and M. Berry. 2006. “Geographical Visual ization: A Participatory Planning Support Tool for Imagining Landscape Futures." Applied GIS 2 (3): 22.

Portman, M.E., A. Natapov, and D. Fisher-Gewirtzman. 2015. “To Go Where No Man Has Gone Before: Virtual Reality in Architec-ture, Landscape Architecture and Environmental Planning." Computers, Environment and Urban Systems, 54: 376-84.
Prudencio, L., and S.E. Null. 2018. "Stormwater Management and Ecosystem Services: A Review." Environmental Research Letters 13 (3): 033002.

Riggs, W.W. 2017. “Deconstructing Howard Through the Lens of Hall: Lessons from the Garden City Reformer." Focus 14 (1): 22.

Rizwan, A.M., L.Y. Dennis, and L.I.U. Chunho. 2008. "A Review on the Generation, Determination and Mitigation of Urban Heat Island." Journal of Environmental Sciences 20 (1): 120-8.

Ro, C., C. Sovann, D. Bun, C. Yim, T. Bun, S. Yim, and K.N. Irvine. 2020. "The Economic Value of Peri-Urban Wetland Ecosystem Services in Phnom Penh, Cambodia: Methodology and Preliminary Results." In International Conference of Science and Applied Geography. Depok, Indonesia: IOP.

Roseland, M. 1997. "Dimensions of the Eco-city." Cities 14 (4): 197-202.

Rybczynski, W. 1999. "Why We Need Olmsted Again." Wilson Quarterly 23: 15-21.

Saarikoski, H., J. Mustajoki, D.N. Barton, D. Geneletti, J. Langemeyer, E. Gomez-Baggethun, and R. Santos. 2016. "Multi-Criteria Decision Analysis and Cost-Benefit Analysis: Comparing Alternative Frameworks for Integrated Valuation of Ecosystem Services. Ecosystem services 22: 238-49.

Sanders, R.A. 1986. “Urban Vegetation Impacts on the Hydrology of Dayton, Ohio." Urban Ecology 9 (3-4): 361-76.

Scholte, S.K., A. van Teeffelen, and P.H. Verburg. 2015. "Integrating Socio-cultural Perspectives into Ecosystem Service Valuation: A Review of Concepts and Methods." Ecological Economics 114: 67-78.

Scott, A., C. Carter, K. Brown, and V. White. 2009. "'Seeing is Not Everything': Exploring the Landscape Experiences of Different Publics." Landscape Research 34 (4): 397-424.

Selbig, W.R., and N. Balster. 2010. Evaluation of Turf-Grass and Prairie-Vegetated Rain Gardens in a Clay and Sand Soil, Madison, Wisconsin, Water Years 2004-08. Washington DC: U.S. Geological Survey Scientific Investigations Report 2010-5077.

Serrat-Capdevila, A., J.B. Valdes, and H.V. Gupta. 2011. “Decision Support Systems in Water Resources Planning and Management: Stakeholder Participation and the Sustainable Path to Science-Based Decision-Making." In Efficient Decision Support Systems-Practices and Challenges from Current to Future, edited by C. Jao. InTech. https://www.intechopen.com/books/efficient-decision-support-systems-practiceand-challenges-from-current-to-future/ decision-support-systems-in-water-resources-planningand-management-stakeholder-participation-and-th

Sevenant, M., and M. Antrop. 2011. “Landscape Representation Validity: A Comparison between On-Site Observations and Photographs with Different Angles of View." Landscape Research 36 (3): 363-85. 
Sherer, P.M. 2006. The Benefits of Parks: Why America Needs More City Parks and Open Space. San Francisco: The Trust for Public Land.

Shrestha, A., T.A. Chaosakul, D.P. Priyankara, L.H. Chuyen, S.S. Myat, N.K. Syne, and M.S. Babel. 2014. "Application of PCSWMM to Explore Possible Climate Change Impacts on Surface Flooding in a Peri-Urban Area of Pathumthani, Thailand." Journal of Water Management Modeling 22: C377. https://doi.org/ 10.14796/JWMM.C377.

Silva-Hidalgo, H., I.R. Martín-Domínguez, M.T. Alarcón-Herrera, and A. Granados-Olivas. 2009. "Mathematical Modeling for the Integrated Management of Water Resources in Hydrological Basins." Water Resources Management 23 (4): 721-30.

Singh, R.P. 2013. "Sacred Landscapes, Cosmos and Shared Wisdom: The Asian Vision." Keynote Address in The 50th World Congress of IFLA (International Federation of Landscape Architects).

Sitas, N., H.E. Prozesky, K.J. Esler, and B. Reyers. 2014. “Opportunities and Challenges for Mainstreaming Ecosystem Services in Development Planning: Perspectives from a Landscape Level." Landscape Ecology 29 (8): 1315-31.

Smardon, R.C. 1988. "Perception and Aesthetics of the Urban Environment: Review of the Role of Vegetation." Landscape and Urban Planning 15 (1-2): 85-106.

Smardon, R.C. 2016. "Visual Impact Assessment: Where have We Come from and Where are We Going." Journal of Environmental Protection 7 (10): 1331-41.

Smargiassi, A., M.S. Goldberg, C. Plante, M. Fournier, Y. Baudouin, and T. Kosatsky. 2009. "Variation of Daily Warm Season Mortality as a Function of Micro-Urban Heat Islands." Journal of Epidemiology \& Community Health 63 (8): 659-664.

Sothea, K., S. Chansopheaktra, K. Irvine, and K. Duval. 2010. "Phnom Penh Sewer Modeling and Contaminant Load Estimates." Asian Journal of Water, Environment and Pollution 7 (3): 31-8.

Stanley, B.W., B.L. Stark, K.L. Johnston, and M.E. Smith. 2012. "Urban Open Spaces in Historical Perspective: A Transdisciplinary Typology and Analysis." Urban Geography 33 (8): 1089-117.

Strohbach, M.W., E. Arnold, and D. Haase. 2012. "The Carbon Footprint of Urban Green Space-A Life Cycle Approach." Landscape and Urban Planning 104 (2): 220-9.

Swanwick, C., N. Dunnett, and H. Woolley. 2003. “Nature, Role and Value of Green Space in Towns and Cities: An Overview." Built Environment 1978: 94-106.

Tan, J., Y. Zheng, X. Tang, C. Guo, L. Li, G. Song, and H. Chen. 2010. "The Urban Heat Island and Its Impact on Heat Waves and Human Health in Shanghai." International Journal of Biometeorology 54 (1): 75-84.

Tapsuwan, S., G. Ingram, M. Burton, and D. Brennan. 2009. “Capitalized Amenity Value of Urban Wetlands: A Hedonic Property Price Approach to Urban Wetlands in Perth, Western
Australia." Australian Journal of Agricultural and Resource Economics 53 (4): 527-45.

Torgersen, G., J.T. Bjerkholt, and O.G. Lindholm. 2014. "Addressing Flooding and SuDS when Improving Drainage and Sewerage Systems-A Comparative Study of Selected Scandinavian Cities." Water 6 (4): 839-57.

Turner, R.K., S. Georgiou, and B. Fisher. 2011. Valuing Ecosystem Services: The Case of Multi-functional Wetlands. Washington, DC: Earthscan.

Tzoulas, K., K. Korpela, S. Venn, V. Yli-Pelkonen, A. Kazmierczak, J. Niemela, and P. James. 2007. “Promoting Ecosystem and Human Health in Urban Areas using Green Infrastructure: A Literature Review." Landscape and Urban Planning 81: 167-78.

Van Herzele, A., and T. Wiedemann. 2003. "A Monitoring Tool for the Provision of Accessible and Attractive Urban Green Spaces." Landscape and Urban Planning 63 (2): 109-26.

Velarde, J., M. Parejo, J. Blanco, and L. Moruno. 2017. “Use of Video and 3D Scenario Visualisation to Rate Vegetation Screens for Integrating Buildings into the Landscape." Sustainability 9 (7): 1102.

Visoth, T., M. Yim, S. Vathna, K. Irvine, and T. Koottatep. 2010. "Efficiency of Phnom Penh's Natural Wetlands in Treating Wastewater Discharges." Asian Journal of Water, Environment and Pollution 7 (3): 39-48.

Willuweit, L., and J.J. O'Sullivan. 2013. "A Decision Support Tool for Sustainable Planning of Urban Water Systems: Presenting the Dynamic Urban Water Simulation Model." Water Research 47 (20): 7206-20.

Wilson, J., and P. Tyedmers. 2013. "Rethinking What Counts. Perspectives on Wellbeing and Genuine Progress Indicator Metrics from a Canadian Viewpoint." Sustainability 5 (1): 187-202.

Wittig, R. 2008. "Principles for Guiding Eco-City Development." In Ecology, Planning, and Management of Urban Forests. New York: Springer.

Wolch, J.R., J. Byrne, and J.P. Newell. 2014. “Urban Green Space, Public Health, and Environmental Justice: The Challenge of Making Cities 'Just Green Enough"' Landscape and Urban Planning 125: 234-44.

Wong, C.P., B. Jiang, A.P. Kinzig, K.N. Lee, and Z. Ouyang. 2015. "Linking Ecosystem Characteristics to Final Ecosystem Services for Public Policy." Ecology Letters 18 (1): 108-18.

Wong, N.H., and C. Yu. 2005. "Study of Green Areas and Urban Heat Island in a Tropical City." Habitat International 29 (3): 547-58.

Wong, T.C., and B. Yuen, eds. 2011. Eco-city Planning: Policies, Practice and Design. New York: Springer Science \& Business Media.

Wu, G., L. Li, S. Ahmad, X. Chen, and X. Pan. 2013. "A Dynamic Model for Vulnerability Assessment of Regional Water Resources 
in Arid Areas: A Case Study of Bayingolin, China." Water Resources Management 27 (8): 3085-101.

Yau, W.K., M. Radhakrishnan, S.Y. Liong, C. Zevenbergen, and A. Pathirana. 2017. "Effectiveness of ABC Waters Design Features for Runoff Quantity Control in Urban Singapore." Water 9 (8): 577.

Yee, A.T.K., R.T. Corlett, S.C. Liew, and H.T. Tan. 2011. “The Vegetation of Singapore-An Updated Map." Gardens' Bulletin Singapore 63 (1\&2): 205-12.

Yokoya, N., S. Nakazawa, T. Matsuki, and A. Iwasaki. 2014. “Fusion of Hyperspectral and Lidar Data for Landscape Visual Quality Assessment." IEEE Journal of Selected Topics in Applied Earth Observations and Remote Sensing 7 (6): 2419-25.
Yu, C., and W.N. Hien 2006. "Thermal Benefits of City Parks." Energy and Buildings 38 (2): 105-20.

Yuen, B. 1996. “Creating the Garden City: The Singapore Experience." Urban Studies 33 (6): 955-70.

Zevenbergen, C., D. Fu, and A. Pathirana. 2018. "Transitioning to Sponge Cities: Challenges and Opportunities to Address Urban Water Problems in China." Water 10: 1230.

Ziemińska-Stolarska, A., and J. Skrzypski. 2012. "Review of Mathematical Models of Water Quality." Ecological Chemistry and Engineering $S 19$ (2): 197-211.

Zube, E.H., J.L. Sell, and J.G. Taylor. 1982. “Landscape Perception: Research, Application and Theory." Landscape Planning 9 (1): 1-33. 